\title{
Antimalarial efficacy of Pongamia pinnata (L) Pierre against Plasmodium falciparum (3D7 strain) and Plasmodium berghei (ANKA)
}

P.V.V. Satish and K. Sunita*

\section{Abstract}

Background: The objective of the current study was to assess the in vitro antip smodial activities of leaf, bark, flower, and the root of Pongamia pinnata against chloroquine-sensitive Pla od falciparum (3D7 strain), cytotoxicity against Brine shrimp larvae and THP-1 cell line. For in vivo study, olant extract which has shown potent in vitro antimalarial activity was tested against Plasmodium be $\quad$ (ANK * strain).

Methods: The plant Pongamia pinnata was collected from the herbal Conde, of Acharya Nagarjuna University of Guntur district, Andhra Pradesh, India. Sequentially crude extracts of me banol (polar), chloroform (non-polar), hexane (non-polar), ethyl acetate (non-polar) and aqueou (pon of dried leaves, bark, flowers and roots of Pongamia pinnata were prepared using Soxhlet apparatus the ex racts were screened for in vitro antimalarial activity against $P$. falciparum 3D7 strain. The cytotoycity stua of crude extracts were conducted against Brine shrimp larvae and THP-1 cell line. Phytochemicala ly s of the plant extracts was carried out by following the standard methods. The chemical injury to erytriocyt due to the plant extracts was checked. The in vivo study was conducted on P. berghei (ANKA) infecteo ALB/C al, vino mice by following 4-Day Suppressive, Repository, and Curative tests.

Results: Out of all the tested extract, the methanol extract of the bark of Pongamia pinnata had shown an $\mathrm{IC}_{50}$ value of $11.67 \mathrm{\mu g} / \mathrm{mL}$ with potent in itro ant/malarial activity and cytotoxicity evaluation revealed that this extract was not toxic against Brine shrimp an $1+1$ cells. The injury to erythrocytes analysis had not shown any morphological alterations and ae to the erythrocytes after $48 \mathrm{~h}$ of incubation. Because methanolic bark extract of Pongamia pinnata has: onoy,n good antimalarial activity in vitro, it was also tested in vivo. So the extract had exhibited an excener activi vagainst $P$. berghei malaria parasite while decrement of parasite counts was moderately low aria nent $(P<0.05)$ when compared to the control groups, which shown a daily increase of par-sitemia, like the CQ-treated groups. The highest concentration of the extract (1000 mg/kg b.wt./ day) had show $3.90,87.47$ and $94.67 \%$ of chemo-suppression during Suppressive, Repository, and Curative tests respectiva $1 x$ which $z$ most nearer to the standard drug Chloroquine $(5 \mathrm{mg} / \mathrm{kg}$ b.wt./day). Thus, the study has reveal 4 that the methanolic bark extract had shown promisingly high $((P<0.05)$ and dose-dependent chemosuppres n. Th phytochemical screening of the crude extracts had shown the presence of alkaloids, flavonoids, tit. enes, hins, carbohydrates, phenols, coumarins, saponins, phlobatannins and steroids.

Correspondence: sunitakanikaram@gmail.com

Department of Zoology and Aquaculture, Acharya Nagarjuna University,

Nagarjuna Nagar 522510, Guntur district, Andhra Pradesh, India 
(Continued from previous page)

Conclusions: The present study is useful to develop new antimalarial drugs in the scenario of the growing resistance to the existing antimalarials. Thus, additional research is needed to characterize the bioactive molecules of the extracts of Pongamia pinnata that are responsible for inhibition of malaria parasite.

Keywords: Pongamia pinnata, Antimalarial activity, Cytotoxicity evaluation, Phytochemical analysis, $I_{50}$, Selectivity index, Erythrocytic injury

\section{Background}

The word malaria means 'bad air' which was originated from the Italian words 'mal' and 'aria' [1]. Malaria is an extremely dangerous parasitic disease infected by the protozoan parasites Plasmodium falciparum, Plasmodium vivax, Plasmodium malariae and Plasmodium ovale. Moreover, Plasmodium is transmitted to humans by the bite of infective Anopheles mosquito [2].

Malaria was widespread in the twentieth century in more than 100 countries throughout the tropical and subtropical zones including vast areas of Middle and South America, Hispaniola (Haiti and the Dominican Republic), Africa, Southeast Asia, Oceania and the Indian subcontinent. Drug resistance of Plasmodium to all traditional antimalarials and the insecticide resistance of mosquitoes and the finding of newly originated zoonotic parasite species has become problematical to prevent malaria [3].

The year 2015 was an extraordinary year for control due to the three most hot news i.e., ftre $\mathrm{N}$ al Prize was given to Youyou Tu for the discon of arte misinin, the development of first vaccine RTS, gainst $P$. falciparum malaria and the fall of malaria infections worldwide particularly in sub-Sahar a Africa However, there are critical challenges that still orve Attention to boost malaria prevention and ntrol due to the resistance of parasites to antimalaril $1, s$, and the RTS,S vaccines does not prote 0 om $P$ vivax malaria and partially protect from $P$. Icip num nnalaria [4].

According to th $\mathrm{W}$, malaria deaths declined in the year 201 because of the extensive use of insecticide-coated squito nets and combination therapies of artemisinin ,erivatives [5]. In 2012, there were $207 \mathrm{~mL}$ n stilnated cases of malaria in Africa and mo-lity from 473,000 to 789,000 people and most the $a$ were children under fifteen years [6].

ce most dangerous infectious diseases to human yd are AIDS, tuberculosis and malaria [7]. Despite every effort to eliminate the malaria infection, it remains one of the major infections facing by the people living in tropical and subtropical countries. The Indian subcontinent is known for P. vivax and P. falciparum infection, and most of the deaths reported were due to $P$. falciparum infection. Malaria has dramatically increased in India recently, after its near eradication in the early and mid-sixties [8].
Traditionally the plant extracts have/a ays bet $\mathrm{n}$ considered as an important source in the medi e for treatment of malaria. Chloroquine, q inine, and rtemisinin are the most effective antimalar drugs derived from plants. The first successful an nalà. arug quinine was extracted from Cinchona tree; sing on this structure chloroquine and prip ac ne wers derived. The current efficient antimalarial drus Artemisinin was extracted from Chinese pran Artemisıa annua in 1972 [9]. Artemisinin and its ri are used as first-line drugs to treat malaria acce ling to World Health Organization. Regrettab 200\% artemisinin in resistance has been first reported in Thai-Cambodia border and accelerated the need for novel antimalarial drugs [10].

. $v$ the World Health Organization has recommeno $d$ artemisinin and its derivatives as single and in - amisinin combination with other drugs such as amodi quine, lumefantrine, mefloquine, sulphadoxine- pyrimethamine (SP) as the first-line therapy for malaria worldwide [11]. As a result of this fact, the search for novel plant-derived antimalarial remedies began.

Thus the present investigation was focused to study the antimalarial activity of the plant Pongamia pinnata. Pongamia pinnata (L) Pierre commonly called as 'Kanuga Tree', one of the most growing and popular plants of India. The 'Pongamia' name was originated from the Tamil, and 'pinnata' means 'Pinnate leaves.' This plant belongs to 'Leguminosae' family and its subfamily is 'Papilionaceae.' In Telugu (local language) this is known as 'Ganuga' or 'Kanuga'. The plant is known as 'Pungai,' in Tamil, 'Karanj' in Hindi, 'Karach' in Bengali and 'Pongamoil tree' in English language.

Pongamia pinnata is a medium-sized ever green IndoMalaysian species, commonly grown on alluvial and coastal habitats from India to Fiji, starting from sea level to $1200 \mathrm{~m}$. Recently it is introduced in Florida, Australia, Malaysia, Hawaii, Seychelles, Philippines and Oceania as an exotic species. This plant stands as painted in crimson color in the months of March and April for about a week because of the buds developing with new leaves and then after the leaves grow mature, the tree acquires a beautiful bright lime-green color. Pongamia pinnata is predominantly cultivated in a large number of gardens and along with many roads in India and is becoming one of the most desirous trees of the city [12]. 
It has a number of phytochemical constituents belonging to a group of fixed oils and flavonoids. In folk medicine, sprouts and fruits of Pongamia pinnata are used as a remedy for tumors. Leaves are active against Micrococcus, due to the reason it is used for healing of cold, cough, dyspepsia, diarrhea, leprosy, flatulence and gonorrhea. The plant roots are mainly used for cleaning of teeth, teeth gums and ulcers. The bark is used as medicine for treatment of bleeding piles. Juices and oils of Pongamia are antibacterial and antiseptic. In the traditional medical practices like Unani and Ayurveda, the Pongamia pinnata plant and its parts are used for antiinflammatory, antiplasmodial, antilipidoxidative, antinonciceptive, antihyperglycaemic, antidiarrheal, antiulcer, antihyperammonic and antioxidantagent [13].

\section{Methods}

\section{Collection of plant and its parts}

Fresh samples of leaves, bark, flowers and roots of Pongamia pinnata were collected from Acharya Nagarjuna University's Herbal Garden of Guntur district, Andhra Pradesh, India (Fig. 1). The confirmation of the plant species was done by Prof. S.M. Khasim, Department of Botany, Acharya Nagarjuna University, Guntur district, Andhra Pradesh, India. The voucher specimen of Pongamia pinnata was deposited in the Department of Botany, Acharya Nagarjuna University. All plant part ve ? washed immediately after collection with tap water of distilled water to remove the adhering or 5 isms an dirt.

\section{Extract preparation}

The methanol (polar), chloroform $(n-p o l a r)$, hexane (non-polar), ethyl acetate (no molar) and aqueous or water (polar) crude extracts we e ared from shadedried plant parts of le bark flowers and root in a Soxhlet apparatus oro ${ }^{11}$ at $50-60^{\circ} \mathrm{C}$ [14]. After complete extraction, the "ltrates were concentrated separately by rota ncuum aporation $\left(>45^{\circ} \mathrm{C}\right)$ and then freeze dried $(-20$ to obtain solid residue. The percent of extraction was qulculated by using the following formula

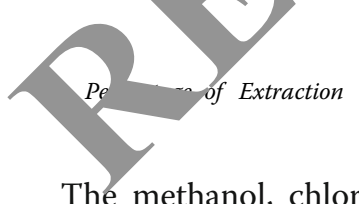

$$
\frac{\text { Weight of the extract }(g)}{\text { Weight of the plant material }(g)} \times 100
$$

The methanol, chloroform, hexane, ethyl acetate and aqueous extracts of leaf, bark, flower and root were screened for the presence of phytochemicals according to the method of Sofowora [15] and Kepam [16]. These extracts were then dissolved in dimethyl sulphoxide (DMSO) and were filtered through 'millipore sterile filters' (mesh $0.20 \mu \mathrm{m}$, Sartorious Stedim Biotech GmbH, Germany).

\section{Parasite cultivation}

The $P$. falciparum strain was obtained from ongoing cultures in the departmental laboratory of the University. They were cultured according to the method of Trager and Jenson (1976) in candle jar desiccators. Then the Plasmodium falciparum culture was further cultiveted in human $\mathrm{O}^{\mathrm{Rh}+}$ red blood cells using RPMI 1640 medium (Sigma Laboratories Private Limited, Mumba racia) supplemented with $\mathrm{O}^{\mathrm{Rh}+}$ serum $(10 \%), 5 \%$ sodium bonate and $50 \mu \mathrm{g} / \mathrm{mL}$ of gentamycin suh Hem tocrits were adjusted at $2 \%$ and cultures $\sigma^{2}$ paras were used when they exhibited $2 \%$ parasitem a [17].

\section{In vitro antimalarial screenirig imo. et al., 2001)}

The P. falciparum culty susp vion of 3D7 (synchronized with $5 \%$ sor 1 it to rin/ stage) was seeded $(200 \mu \mathrm{L} /$ well with $2 \%$ ring res and $2 \%$ haematocrit) in 96-well tissue caltu plates The plant extracts (methanol, chloroforn he ethyl acetate and aqueous extracts of leaf, b flower and root) of Pongamia pinnata addea to these wells in different concentrations $(200,10,50,25$, and $12.5 \mu \mathrm{g} / \mathrm{mL})$. Chloroquine treated parisites were kept as 'control positive' and Dh. Treated parasites were kept as 'control negative' rroul. The parasites were cultured for $30 \mathrm{~h}$ in candle , desiccators. The cultures were incubated at $37^{\circ} \mathrm{C}$ for $48 \mathrm{~h}$ in an atmosphere of $2 \% \mathrm{O}_{2}, 5 \% \mathrm{CO}_{2}$ and $93 \% \mathrm{~N}_{2}$. At $18 \mathrm{~h}$ before termination of the assay, $\left[{ }^{3} \mathrm{H}\right]$ Hypoxanthine $(0.5 \mu \mathrm{Ci} /$ well $)$ was added to each well. The effect of extracts in the cultures was evaluated by the measurement of $\left[{ }^{3} \mathrm{H}\right]$ Hypoxanthine incorporation into the parasite nucleic acids [18]. Each treatment has four replicates; at the end of the experiment, one set of the parasite infected red blood cells were collected from the wells, and blood smears were prepared. These smears were fixed with methanol and air dried. The smears were stained with Acridine Orange (AO) and Giemsa stain. Stained smears were observed under UV illumination microscope (Carl Zeiss) for confirmation of $\left[{ }^{3} \mathrm{H}\right]$ Hypoxanthine assay. The experiment was terminated and the cultures were frozen and stored at $-20^{\circ} \mathrm{C}$. The parasites were harvested on glass filter papers using NUNC Cell Harvester and CPM (count per minute) was recorded in gamma scintillation counter. Control readings were considered to be as $100 \%$ parasite growth and the parasite inhibition was calculated for plant extract treated samples. The parasite inhibition was calculated as follows (19):

$$
\% \text { Inhibition }=\frac{\text { Average CPM of Control }- \text { Average CPM of plant extract }}{\text { Average CPM of Control }} \times 100
$$

The $\mathrm{IC}_{50}$ values were determined by plotting concentration of extract on $\mathrm{X}$-axis and percentage of inhibition 


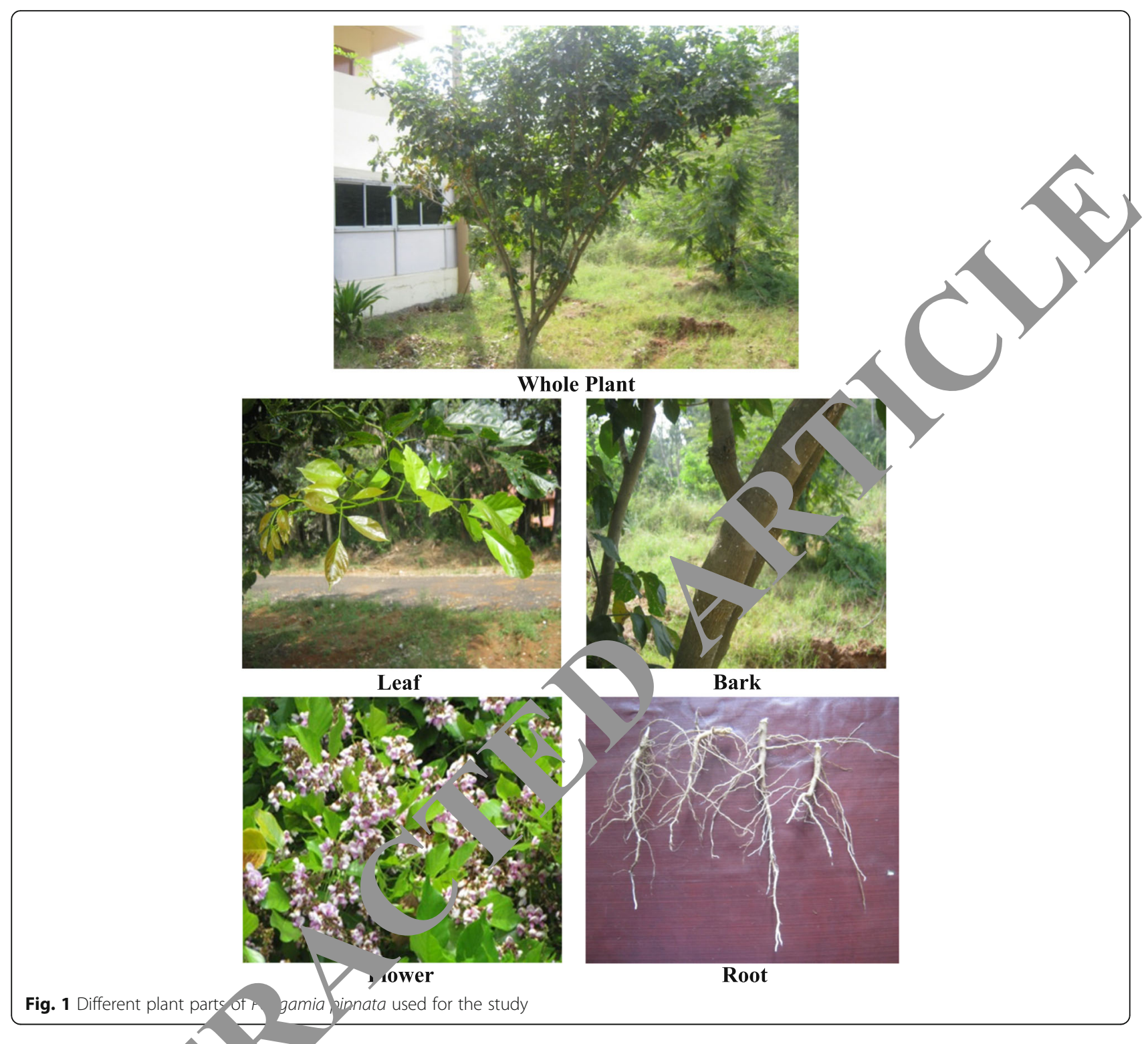

on Y-axis wi tose-res, onse curves using Minitab 11.12.32. Bit softw.

The in vitro antipla modial activity of the extracts was categor 1 to four groups based on $\mathrm{IC}_{50}$ value i.e., $<5 / \mathrm{mL}$ very active, $5-50 \mu \mathrm{g} / \mathrm{mL}$ - active, 50- $0 \mu / \mathrm{mL}$ - weakly active, $>100 \mu \mathrm{g} / \mathrm{mL}$ - inactive [19].

Brinc 'Trimp lethality assay (BSLA) (in vivo assay)

In the present study, the brine shrimp larvae were collected from hatched eggs of Artemia salina cultured in artificial sea water $(20 \mathrm{~g} \mathrm{NaCl}$ and $18 \mathrm{~g}$ table salt in 11 of distilled water) for $24 \mathrm{~h}$ at room temperature $\left(25-30^{\circ} \mathrm{C}\right)$. The crude extracts (methanol, chloroform, hexane, ethyl acetate and aqueous extracts of leaf, bark, flower and root) of Pongamia pinnata were dissolved in DMSO in different concentrations of 100, 200, 400, 600, 800, 1000, 1200, 1400, 1600 and $1800 \mu \mathrm{g} / \mathrm{mL}$ were added to each test tube containing 10 live nauplii in $10 \mathrm{~mL}$ of artificial sea water. The solvent (DMSO) concentration was not more than 5\% and had no adverse effects on the larvae. The same procedure was followed for the standard drug chloramphenicol (control positive) and the final volume for each test tube was made up to $10 \mathrm{ml}$ with artificial sea water with ten live nauplii in each test tube. The 'control negative' test tube with DMSO contained 10 live nauplii in $10 \mathrm{~mL}$ of artificial sea water. After 24 $h$, the test tubes were observed and the number of survived nauplii in each test tube was counted and the results were noted. The percentage of dead nauplii in the test and the standard group was established by comparing with that of the control group. The percentage of mortality was plotted against log 
concentrations, and the lethal concentrations $\left(\mathrm{LC}_{50}\right)$ was deliberated by Finney's probit analysis [20]. The general toxicity activity was considered weak when the $\mathrm{LC}_{50}$ ranged from $500 \mu \mathrm{g} / \mathrm{mL}$ to $1000 \mu \mathrm{g} / \mathrm{mL}$, moderate when the $\mathrm{LC}_{50}$ ranged from $100 \mu \mathrm{g} / \mathrm{mL}$ to $500 \mu \mathrm{g} / \mathrm{mL}$ and strong when the $\mathrm{LC}_{50} \mathrm{is} \leq 100 \mu \mathrm{g} / \mathrm{mL}$ [21]. In vivo selectivity index (SI) was determined for each extract as follows:

$$
S I=\frac{\text { LC50 of Brine shrimp }}{\text { LC50 of P. falciparum }}
$$

\section{Cytotoxicity of extracts to THP-1 monocyte cells}

Cytotoxicity studies of the crude extracts (methanol, chloroform, hexane, ethyl acetate and aqueous extracts of leaf, bark, flower and root) of Pongamia pinnata were conducted by functional assay using THP-1 cells [22]. $10 \%$ fetal bovine serum, $0.21 \%$ sodium bicarbonate (Sigma), and $100 \mu \mathrm{g} / \mathrm{mL}$ penicillin and $50 \mu \mathrm{g} / \mathrm{mL}$ gentamicin (complete medium) containing RPMI-1640 (Roswell Park Memorial Institute 1640) medium was used for the culture of cells. Briefly, cells $\left(0.2 \times 10^{6}\right.$ cells/ $200 \mu \mathrm{L} /$ well) were seeded into 96-well culture plates in complete medium. The plant extracts $(200,100,50,25$ and $12.5 \mu \mathrm{g} / \mathrm{mL}$ ) were added after $24 \mathrm{~h}$ of seeding and incubated for $48 \mathrm{~h}$ in a humidified atmosphere at $37{ }^{\circ} \mathrm{C}$ and $5 \% \mathrm{CO}_{2}$. DMSO and ellipticine were kept as $\mathrm{c}$ ntrol negative and control positive respectively. After te. ation of the experiments $10 \mu \mathrm{L}$ of MTT ste $k$ solut $(5 \mu \mathrm{g} / \mathrm{mL}$ in $1 \times \mathrm{PBS})$ was added to eac $\mathrm{h}$ gently mixed and incubated for another four hours. Th yates were centrifuged at $1500 \mathrm{rpm}$ for $5 \mathrm{~min}$; the supernatants were discarded, subsequently dded $00 \mu \mathrm{L}$ of DMSO (stopping agent) in each well. lormation of formazan, it was read on a mici nlate reader (Versa max tunable multi well plate reader) at $570 \mathrm{~nm}$, and the percentage of cell via -1lity vas cl culated using the following formula $[23]$.

\% Cell Via lity Mea absorbance in test wells Mea absorbance in test wells $\times 100$

The $C$ of in vitro toxicity was calculated for each extract usin . he fo iowing formula:

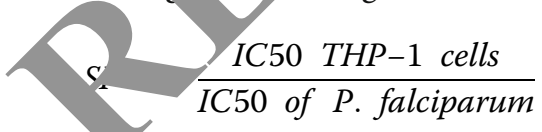

The $\mathrm{IC}_{50}$ values were determined by plotting the concentration of extract on $\mathrm{X}$-axis and percentage of cell viability on $\mathrm{Y}$-axis with dose-response curves using Minitab 11.12.32. Bit software.

\section{Chemical injury to erythrocytes}

To assess the chemical injury to erythrocytes due to the plant extracts (methanol, chloroform, hexane, ethyl acetate and aqueous extracts of leaf, bark, flower and root) of Pongamia pinnata; $200 \mu \mathrm{L}$ of erythrocytes were incubated with $200 \mu \mathrm{g} / \mathrm{mL}$ of the extract, a dose equal to that of the highest dose used in the antiplasmodial assay. The experiments were conducted under the same conditions as that of the antiplasmodial assay. After $4^{\circ} \mathrm{h}$ of incubation, the assay was terminated and th n blood smears were prepared and fixed with methano a air dried. These smears were stained with Giemsa sta $\mathrm{d}$ observed for morphological variations - rythro ytes if any, under a light microscope. Ticse rpbological findings were compared with the lormal eryt, irocytes of the control group [24].

\section{Extracts dilutions}

The methanol, chlor or aqueous extracts of leaves bark, flowers and roots of Pongamia pinn ta ere first dissolved in DMSO to prepare a stock co. $\quad 1$ of $50 \mathrm{mg} / \mathrm{mL}$. Then the stock solution was dilu in RPMI 1640 medium to make $10 \mathrm{mg} / \mathrm{m}$ working concentration for in vitro (P. falciparum and $1 \mathrm{r}, \mathrm{s}-1$ cells) studies. From the above working solutior different concentrations of crude extracts ( $\mathrm{m}$ anol, chloroform, hexane, ethyl acetate and aqueous $t$ tracts of leaf, bark, flower and root) such as 12.5 , $5 \%, 100$ and $200 \mu \mathrm{g} / \mathrm{mL}$ were prepared by serial dilution [25] for antimalarial screening against CQ-sensitive P. falciparum 3D7 strain and to test cytotoxicity against THP-1 cell line.

Moreover, a working solution of $50 \mathrm{mg} / \mathrm{mL}$ was prepared for in vivo (brine shrimp and mice) studies. The concentrations from 100 to $1600 \mu \mathrm{g} / \mathrm{mL}$ were prepared by serial dilution for toxicity against brine shrimp. The plant extract concentrations from 200 to $1000 \mathrm{mg} / \mathrm{kg}$ were prepared with PBS (phosphate buffered saline) for in vivo antimalarial activity against $P$. berghei in BALB/c mice.

\section{In vivo study of Methanolic bark extract}

Healthy BALB/c female mice of age 6-8 weeks (25$30 \mathrm{~g})$ were used for the present investigation. The mice were fed on standard pellet diet and water was given ad libitum. They were kept in clean, dry polypropylene cages and maintained in a well-ventilated animal house with $12 \mathrm{~h}$ light $/ 12 \mathrm{~h}$ dark cycle. Animal experiments were conducted according to the guidelines of Institutional Animal Ethics Committee of Hindu College of Pharmacy, Guntur (IAEC Ref. No. HCOP/IAEC/PR-21/ 2014), Andhra Pradesh, India.

The chloroquine sensitive Plasmodium berghei ANKA strain was maintained in vivo in BALB/c mice in our laboratory by weekly inoculation of $1 \times 10^{7}$ infected red blood cells in naïve mice. Then the parasitemia was counted with a hemocytometer and adjusted the 
parasites $0.5 \times 10^{6}$ in PBS sterile solution. Each animal was injected intraperitoneally (IP) with $200 \mu \mathrm{L}(0.2 \mathrm{~mL})$ with $0.5 \times 10^{6}$ parasites inoculated on the first day i.e., day-0 [26].

For evaluating the methanol bark crude extract, infected mice were randomly divided into seven groups of 3 mice per group. Group I to Group V were treated with the methanol bark extract (most effective among all the other extracts) of Pongamia pinnata at doses of $200 \mathrm{mg} /$ $\mathrm{kg}, 400 \mathrm{mg} / \mathrm{kg}, 600 \mathrm{mg} / \mathrm{kg}, 800 \mathrm{mg} / \mathrm{kg}$ and $1000 \mathrm{mg} / \mathrm{kg}$ respectively. The remaining two groups were maintained as control negative and control positive; and administered PBS and chloroquine with $5 \mathrm{mg} / \mathrm{kg}$ body weight/ day respectively.

\section{The 4-day suppressive test}

This test was used to evaluate the schizonticidal activity of the methanolic extract of the bark of Pongamia pinnata against $P$. berghei infected mice according to the method described by Peter et al. [27]. These infected mice were randomly divided into the respective groups as described above. Then the treatment was started three hours after mice had been inoculated with the parasites on day- 0 and then continued daily for four days from day-0 to day-3. After completion of treatment, thin blood film was prepared from the tail of each anim on day- 4 to determine parasitemia and percentage of hil. ition. Additionally, each mouse was observed daily $r$ determination of survival time.

\section{Evaluation of the repository activity}

Evaluation of repository activity was conducted according to the method described by Peter 91 . [2/]]. Initially, five groups of mice ( 3 mice in h group) were administered intraperitoneally (IP) with y ethanolic extract of the bark of Pongam innat a chloroquine (control positive) and PBS (ch rol arative) for four consecutive days (D0-D3) respecti as described above. On the fifth day (D4) mice ere inoculated with Plasmodium berghei infec red blood cells. Seventy-two hours later, the parasitemic level was evaluated by observing Giemsa i..d Nood smears. Also, the mice were obser- dun the study period for determination of surval me.

\section{Rant Test or curative test}

To evaluate the curative potential of the methanolic crude extract of bark of Pongamia pinnata, the most active fraction in Peter's test was evaluated according to the method described by Ryley and Peters [28]. On day0 , a standard inoculums of $0.5 \times 10^{6}$ infected erythrocytes was inoculated into each mouse intraperitoneally (IP). After seventy-two hours, mice were randomly divided into their respective groups and administrated the extract once daily for five days. Giemsa-stained thin blood film was prepared from the tail of each mouse daily for five days to monitor parasitemia level. Mean survival time for each group was determined arithmetically by calculating the average survival time (days) of mice starting from the date of infection over a period of 30 days (D0-D29).

\section{Parasitemia measurement}

Thin smears of blood were made fron e tail If each mouse at the end of each test. The cincars - prepared on glass slides $(76 \times 26 \mathrm{~mm})$, fixe with absol ate methanol for $15 \mathrm{~min}$ and stained witl $10 \%$ Giemsa stain at $\mathrm{pH} 7.2$ for $15 \mathrm{~min}$. And wer 'so d acridine Orange. The stained slides $w$ then washed gently using distilled water $\mathrm{n}_{\mathrm{c}}$ ir dried at room temperature. Two stained slides for each ouse were examined under a Trinocular micro ope (C-4i20) and UV illumination microscope ( $\mathrm{Ca} \quad$ hder 1000× magnification. Ten fields on each slic were observed to calculate the percent of pa +amia 29$]$.

$$
\text { Parasite, fia }(\%)=\frac{\text { No. parasitized } R B C}{\text { Total No. of } R B C} \times 100
$$

Als the percentage of parasitemia suppression due to th. effect extracts was calculated using the following ormula.

$$
\text { Suppression }(\%)=\frac{\text { Mean parasitemia of control negative group }}{\text { Mean parasitemia of treated group }} \times 100
$$

\section{Monitoring of body weight}

For Peter's test, the body weight of each mouse was measured before infection (day 0 ) and on day 4 using a sensitive digital weighing balance. For Rane's test, body weight was measured before infection and from day 3-7 after infection. For repository test, body weight was measured before dosing periods and on dosing periods.

\section{Packed cell volume measurement}

Packed cell volume (PCV) was measured to predict the effectiveness of the test extract in preventing hemolysis resulting from increasing parasitemia associated with malaria. Heparinized capillary tubes were used for collection of blood from the tail of each mouse. The capillary tubes were filled with blood up to $34^{\text {th }}$ of their volume and sealed at the dry end with sealing clay. The tubes were then placed in a micro-haematocrit centrifuge with the sealed end outwards and centrifuged for $5 \mathrm{~min}$ at $11,000 \mathrm{rpm}$. The tubes were then taken out of the centrifuge and PCV was determined using a standard Micro-Hematocrit Reader. The PCV is a measure of the proportion of RBCs to plasma and measured before 
inoculating the parasite and after treatment using the following formula [30]:

$$
\text { PCV }(\%)=\frac{\text { Volume of erythrocytes in given volume of blood }}{\text { Total blood volume }} \times 100
$$

\section{Statistical analysis}

The mean and standard deviations of the treated and control groups were calculated at 95\% confidence intervals for inhibition, mortality, parasitemia, body weight and PCV. The results were analyzed statistically by twotailed student's t-test to identify the differences between the treated group and control group with Minitab 11.12.32. Bit software. The data was considered significant at $P<0.05$.

\section{Results}

\section{Yield of crude extracts from Pongamia pinnata and it's} phytochemicals

The weight of leaves, bark, flowers and roots extracts of Pongamia pinnata in methanol, chloroform, hexane, ethyl acetate and aqueous respectively were shown in Table 1. The percent yield of extracts varied from 1.48\% to $15.32 \%$. It was revealed that, chloroform extract of flowers $(15.32 \%)$ shown highest percent yield followea

Table 1 Weight and percentage yield of different crude rad's of Pongamia pinnata

\begin{tabular}{|c|c|c|c|c|}
\hline Plant part & Extract & $\begin{array}{l}\text { Wight of plant part } \\
\text { (g) }\end{array}$ & $\begin{array}{l}\text { Wigh } \\
\text { (g) }\end{array}$ & $\begin{array}{l}\text { Yiè, } \\
(\%)\end{array}$ \\
\hline \multirow[t]{5}{*}{ Leaf } & ME & 50 & 3.24 & 6.48 \\
\hline & $\mathrm{CH}$ & 50 & 4.5 & 9.08 \\
\hline & $\mathrm{HE}$ & 50 & 7.45 & 14.90 \\
\hline & EA & 50 & & 1.48 \\
\hline & $A Q$ & 50 & & 4.54 \\
\hline \multirow[t]{10}{*}{ Bark } & ME & 50 & .23 & 4.46 \\
\hline & $\mathrm{CH}$ & & 4.56 & 9.12 \\
\hline & $\mathrm{H}$ & & 7.11 & 14.22 \\
\hline & & & 1.27 & 2.54 \\
\hline & & & 3.51 & 7.02 \\
\hline & & 0 & 4.51 & 9.02 \\
\hline & & 50 & 7.66 & 15.32 \\
\hline & & 50 & 6.08 & 12.16 \\
\hline & EA & 50 & 1.33 & 2.66 \\
\hline & $A Q$ & 50 & 3.54 & 7.08 \\
\hline \multirow[t]{5}{*}{ Root } & ME & 50 & 2.23 & 4.46 \\
\hline & $\mathrm{CH}$ & 50 & 2.98 & 5.96 \\
\hline & HE & 50 & 6.21 & 12.42 \\
\hline & EA & 50 & 1.92 & 3.84 \\
\hline & $A Q$ & 50 & 2.22 & 4.44 \\
\hline
\end{tabular}

ME Methanol, $C H$ Chloroform, $H E$ Hexane, $E A$ Ethyl acetate, $A Q$ Aqueous by hexane extract of leaves (14.90\%). The phytochemical screening has revealed the presence of various phytochemical compounds in the methanol, chloroform, hexane, ethyl acetate and aqueous extracts of leaves, bark, flowers and roots of Pongamia pinnata. But flavonoids are the common phytochemicals found in the evtracts excepting in the root extracts (Table 2).

\section{In vitro antimalarial activity}

The present experimentation evaluacd th nti halarial activity of the crude extracts of methany, hexane, chloroform, ethyl acetate and aqu us frorh leaves, bark, flowers and roots of Pongarm ninm $\quad \mathrm{I}_{\mathrm{m}} \mathrm{IC}_{50}$ values of the plant extracts terea aga t Plasmodium falciparum are shown in T:D

The $\mathrm{IC}_{50}$ value of the $\mathrm{n}$ hanol, chloroform, hexane, ethyl acetate na queous extracts of leaves, bark, flowers and ro amia pinnata showed a range $\left(\mathrm{IC}_{50}=11.67 \mu \mathrm{g} / \mathrm{h}\right.$ to $\left.178.41 \mu \mathrm{g} / \mathrm{mL}\right)$ of inhibitory concentration ninst \&Q-sensitive P. falciparum strain.

The metho $1 \mathrm{O}_{1}, \mathrm{c}$ extract of leaves $(24.00 \mu \mathrm{g} / \mathrm{mL})$, bark (11.67 $\mu \mathrm{g} / \mathrm{mL})$, flowers $(32.00 \mu \mathrm{g} / \mathrm{mL})$ and roots (20 $\mu \mathrm{g} / \mathrm{mL})$; aqueous extract of bark $(37.18 \mu \mathrm{g} / \mathrm{mL})$, flowe $(42.42 \mu \mathrm{g} / \mathrm{mL})$ and ethyl acetate extract of bark $\mu \mathrm{g} / \mathrm{mL}$ ) showed $\mathrm{IC}_{50}$ values $<50 \mu \mathrm{g} / \mathrm{mL}$ which wêre significant at $P<0.05$ indicating good antimalarial activity. Among these extracts methanol extract of bark showed very minimal $\mathrm{IC}_{50}$ value $(11.67 \mu \mathrm{g} / \mathrm{mL})$ showing better antimalarial activity than the other extracts [19].

The ethyl acetate extracts of leaves $(70.33 \mu \mathrm{g} / \mathrm{mL})$ and flowers $(58.00 \mu \mathrm{g} / \mathrm{mL})$; the aqueous extracts of leaves $(92.00 \mu \mathrm{g} / \mathrm{mL})$ and roots $(88.00 \mu \mathrm{g} / \mathrm{mL})$ showed $\mathrm{IC}_{50}$ values between 50 and $100 \mu \mathrm{g} / \mathrm{mL}$ indicating weak antimalarial activity.

The chloroform extract of bark and hexane extract of flower showed $\mathrm{IC}_{50}$ values greater than $200 \mu \mathrm{g} / \mathrm{mL}$ indicating inactivity against malaria parasite. And the $\mathrm{IC}_{50}$ values of chloroform and hexane extracts of leaves and roots were not determinate due to their unclear inhibition [19].

Out of the 20 extracts tested; seven extracts have shown active $\left(\mathrm{IC}_{50}=11.67\right.$ to $\left.46.57 \mu \mathrm{g} / \mathrm{mL}\right)$ antimalarial activity, four extracts have shown weak $\left(\mathrm{IC}_{50}=58.00\right.$ to $92.00 \mu \mathrm{g} / \mathrm{mL}$ ) antimalarial activity, while nine extracts have no antimalarial activity $\left(\mathrm{IC}_{50}=>100 \mu \mathrm{g} / \mathrm{mL}\right)$. Thus methanolic extract of bark has shown very minimal $\mathrm{IC}_{50}$ value $(11.67 \mu \mathrm{g} / \mathrm{mL})$ with excellent antimalarial activity when compared to the activity of other tested extracts.

The microscopic observation of inhibition of Plasmodium falciparum by treatment with methanolic extracts $(200 \mu \mathrm{g} / \mathrm{mL})$ is shown in Figs. 2 and 3. The CPM values after the treatment of all the extracts at the highest concentration of $200 \mu \mathrm{g} / \mathrm{mL}$ are represented in Fig. 4. 
Table 2 Phytochemical constituents of Pongamia pinnata in different extracts of leaf, bark, flower and root

\begin{tabular}{|c|c|c|c|c|c|c|c|c|c|c|c|c|c|}
\hline \multirow{2}{*}{$\begin{array}{l}\text { Tested } \\
\text { compounds }\end{array}$} & \multicolumn{5}{|l|}{ Leaf } & \multicolumn{5}{|l|}{ Bark } & \multicolumn{3}{|c|}{ Flower } \\
\hline & $\overline{\mathrm{ME}}$ & $\mathrm{CH}$ & $\mathrm{HE}$ & EA & $\overline{A Q}$ & $\overline{\mathrm{ME}}$ & $\mathrm{CH}$ & $\mathrm{HE}$ & EA & $\overline{\mathrm{AQ}}$ & $\overline{\mathrm{ME}}$ & $\mathrm{CH}$ & $\mathrm{HE}$ \\
\hline Alkaloids & - & - & - & + & - & - & - & - & + & - & - & - & - \\
\hline Coumarins & + & - & - & - & - & + & - & - & - & - & - & - & - \\
\hline Carbohydrates & - & - & - & - & + & - & - & - & - & + & - & - & - \\
\hline Phenols & + & - & - & + & - & - & - & - & + & - & + & - & - \\
\hline Saponins & - & + & - & + & - & - & + & - & - & - & + & - & - \\
\hline Tannins & + & - & - & + & - & + & - & - & + & - & + & - & - \\
\hline Flavonoids & + & + & + & + & + & + & - & + & - & + & - & - & - \\
\hline Terpenoids & + & - & - & - & - & + & + & - & - & - & + & - & - \\
\hline Phlobatannins & - & - & - & + & - & - & - & - & - & - & - & - & - \\
\hline Steroids & - & + & + & - & - & - & + & + & - & - & - & + & + \\
\hline
\end{tabular}

+ Present, - Absent, ME- Methanol, CH- Chloroform, HE- Hexane, EA- Ethyl acetate, AQ- Aqueous

\section{Cytotoxicity evaluation against brine shrimp}

During cytotoxicity evaluation the methanol, chloroform, hexane, ethyl acetate and aqueous extracts of leaves, bark, flowers and roots showed $\mathrm{LC}_{50}$ values between $480.00 \mu \mathrm{g} / \mathrm{mL}$ to $1475.00 \mu \mathrm{g} / \mathrm{mL}$. In general, the extracts are considered as nontoxic when the $\mathrm{LC}_{50}>1000 \mu \mathrm{g} / \mathrm{mL}$, weak when the $\mathrm{LC}_{50}$ is between $500 \mu \mathrm{g} / \mathrm{mL}$ to $1000 \mu \mathrm{g} / \mathrm{mL}$, moderate when $\mathrm{LC}_{50}$ is between $100 \mu \mathrm{g} / \mathrm{mL}$ to $500 \mu \mathrm{g} / \mathrm{mL}$ and strong when the $\mathrm{LC}_{50}$ is $<100 \mu \mathrm{g} / \mathrm{mL}$. Based on the above classif tio out of the 20 extracts tested, 11 extracts were nont ic $\left(\mathrm{LC}_{50}>1000 \mu \mathrm{g} / \mathrm{mL}\right), 6$ extracts displayed $\mathrm{ak}\left(\mathrm{LC}_{5}\right.$, $500-1000 \mu \mathrm{g} / \mathrm{mL})$ toxicity, 3 extracts exhibited derate toxicity $\left(\mathrm{LC}_{50} 100-500 \mu \mathrm{g} / \mathrm{mL}\right.$ ) and $\mathrm{n}$ one of the e, racts showed $\mathrm{LC}_{50}<100 \mu \mathrm{g} / \mathrm{mL}$ as indice ed in Table 4 . The SI values were calculated and mo of the extracts showed SI value $>10$ indicating the extracts are safer for further studies.

\section{Cytotoxicity evalu-:ion. inst rHP-1 cells}

The cytotoxic; studies twenty different extracts against THP- 1 ce. ne shown $\mathrm{IC}_{50}$ values $>200 \mu \mathrm{g} / \mathrm{mL}$. An extra $t$ was cons, ered as non-toxic if the $\mathrm{IC}_{50}$ was $>20 \mu g$, Sased on the above, the plant extracts were non ${ }^{+}$xic $d$ an be used for further investigations. the value, were also calculated and listed in Table 5.

\section{Chemical injury to erythrocytes}

The microscopic observation of uninfected erythrocytes incubated with the extracts of Pongamia pinnata and uninfected erythrocytes from the blank column of the 96-well plate showed no morphological differences after $48 \mathrm{~h}$ of incubation (Fig. 5). Hence, these extracts are not harmful to erythrocytes during the investigation and are safer to use as a remedy for malaria.
4-Day suppressive

The obtained 'v' nify that, methanolic extracts of Pongamia $p$, ata displayed very good activity against 1 odiu berghei in vivo in BALB/c experimentalma.e. During the study period, the methanol xtract of bark caused a moderately low (1. 0.05) and dose-dependent decrease in parasitomia Inlike the chloroquine treated group, while the tyol negative group shown a daily increase in parasitemia.

During the early infection oral administration of 200, $400,600,800$ and $1000 \mathrm{mg} / \mathrm{kg}$ body weight/day concentration of extract caused chemo-suppression of 14.59, $25.17,36.71,66.25$ and $83.84 \%$ respectively on day- 4 which was significant at $P<0.05$ when compared to control negative. The standard drug chloroquine $(5 \mathrm{mg} /$ $\mathrm{kg}$ b.wt./day) caused 100\% chemo-suppression which was highly significant when compared to the extract treated groups (Table 6). The highest concentration of extract $(1000 \mathrm{mg} / \mathrm{kg}$ b.wt./day) shown $83.84 \%$ chemosuppression which is almost like to that of standard drug chloroquine ( $5 \mathrm{mg} / \mathrm{kg}$ b.wt./day).

The comparative analysis indicated that, methanolic bark extract of Pongamia pinnata showed statistically significant difference on day-4 parasitemia at all dosages when compared to the negative control. The low level of parasitemia was observed at the highest dose $(1000 \mathrm{mg} /$ kg b.wt./day) of methanolic bark extract of Pongamia pinnata with $07.24 \%$ (Table 6) and statistically significant at $P<0.05$.

The mean survival time (MST) of the chloroquine treated mice (control positive) was 30 days \pm 0.00 . The MST of infected mice (control negative) was ten days. The methanolic bark extract MST was significantly higher $(P<0.05)$ than the value of the negative control hence, the MST was lower than the standard drug chloroquine treated mice (Table 6). 


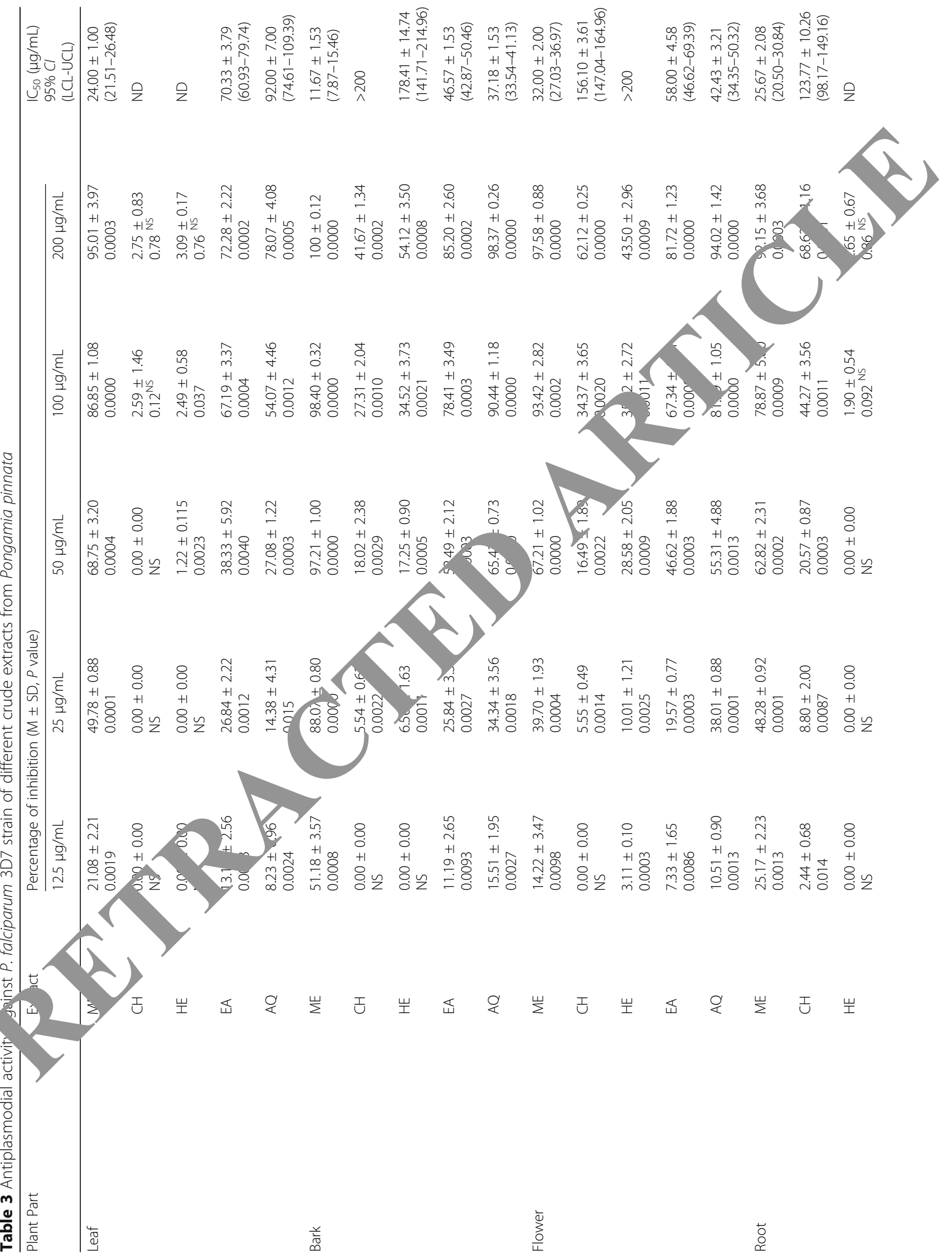




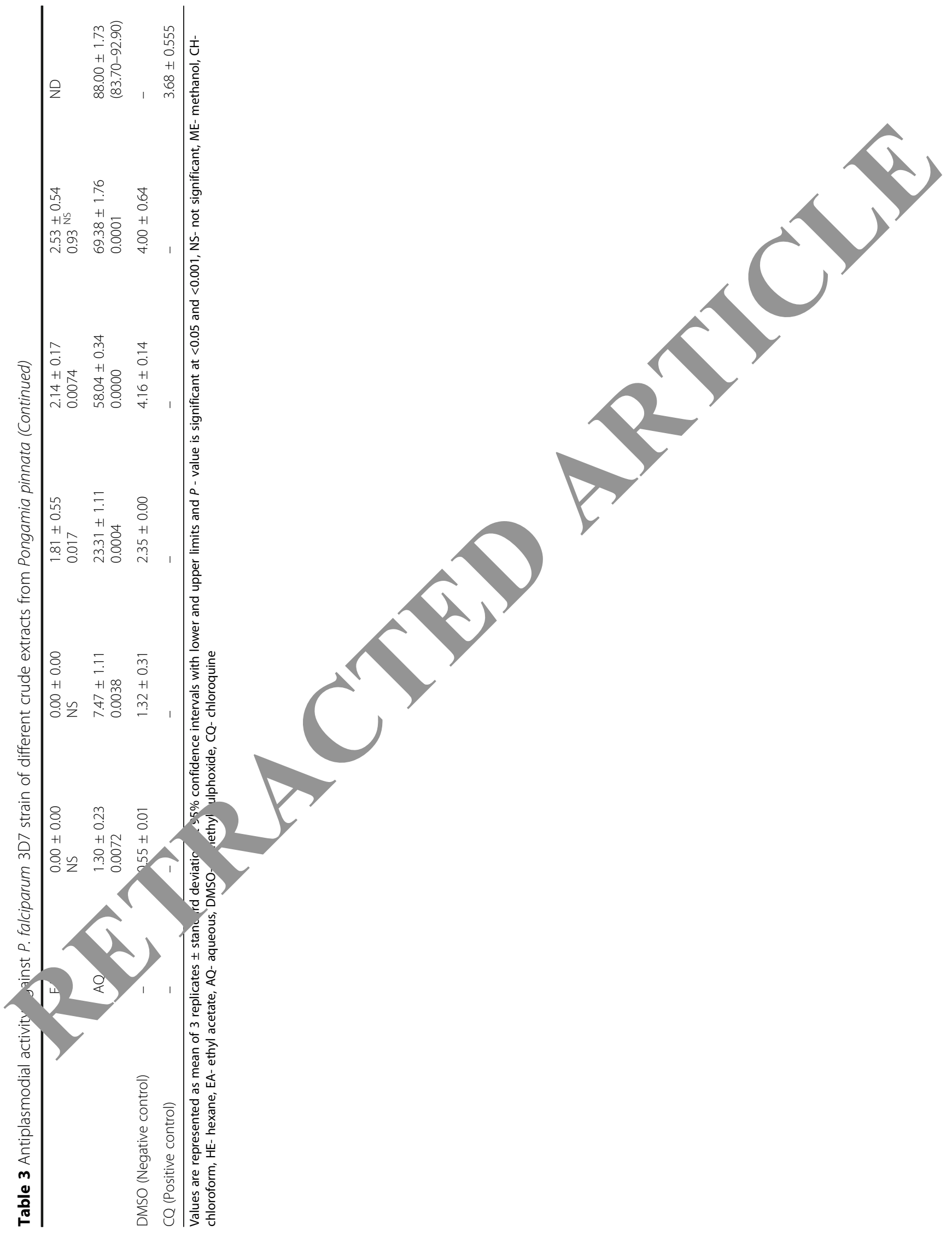




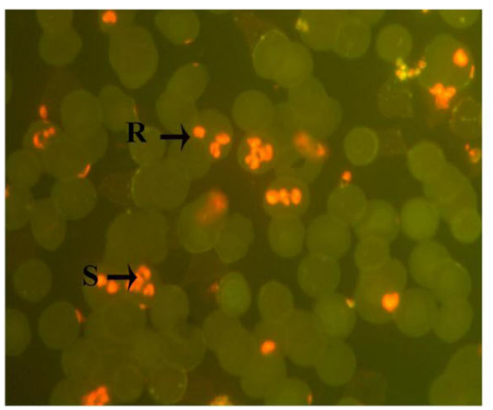

Control Negative

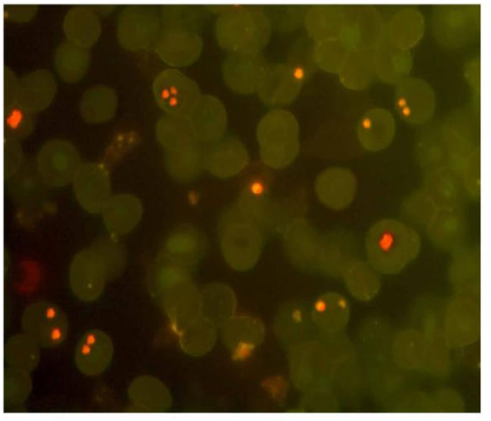

Leaf

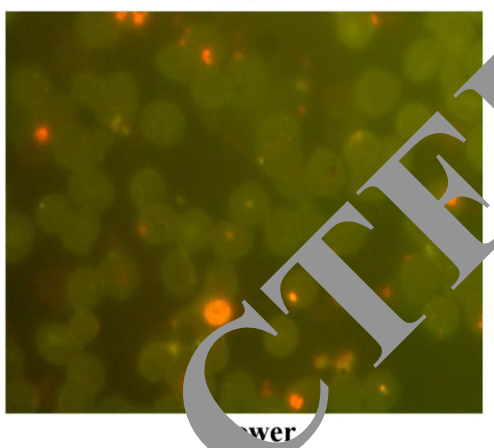

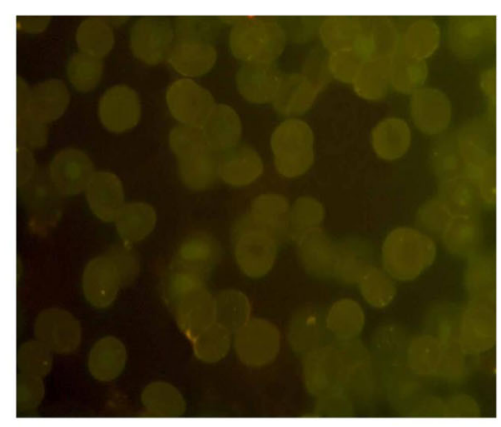

Control Positive

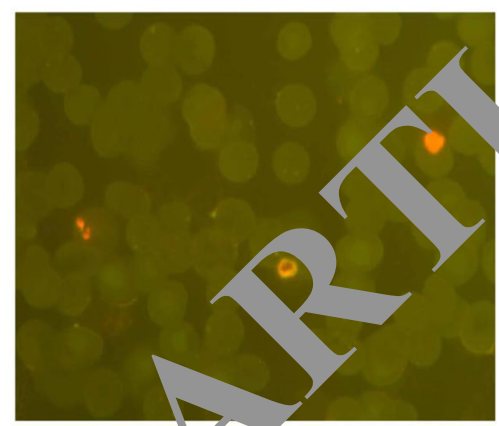

Bark

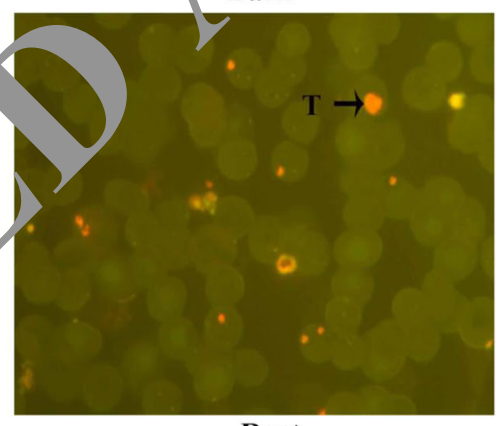

Root

Fig. 2 Microscopic observations after ment with methanolic extracts of Pongamia pinnata against $P$. falciparum 3D7 strain at the highest concentration $(200 \mu \mathrm{g} / \mathrm{mL})$ with Acridir e $0 \mathrm{~m}$ Stain at $1000 \times$ magnification (R- ring stage, T- trophozoite, S- schizont)

In the 4-day suppres test, all the doses of the extract showed a reventiv effect on weight reduction and normalized th weight in infected mice at all dosages who compares to control negative group (Table 6). The t.ano ic bark extract exhibited protective activit gain the reduction in packed cell volume (PCV) vels when sompared to control negative (Table 6).

\section{Repository test}

The methanol bark extract of Pongamia pinnata caused a moderately low $(P<0.05)$ and dose-dependent decrease in parasite counts unlike the chloroquine treated group, while the control group showed a daily increase in parasitemia. At $5 \mathrm{mg} / \mathrm{kg}$ b.wt./day, chloroquine produced $100 \%$ of chemosuppression (Table 7 ). The highest concentration of extract (1000 mg/kg b.wt./day) shown
87.47\% chemo-suppression which was almost similar to that of standard drug chloroquine ( $5 \mathrm{mg} / \mathrm{kg}$ b.wt./day).

The comparative analysis indicated that, methanolic bark extract of Pongamia pinnata showed statistically significant difference in parasitemia compared to the negative control. The low level of parasitemia was observed at highest dose $(1000 \mathrm{mg} / \mathrm{kg}$ b.wt./day) of methanolic bark extract of Pongamia pinnata with $7.32 \%$ (Table 7) and statistically significant at $P<0.05$.

The mean survival time (MST) of the chloroquine treated mice (control positive) was 29 days. The MST of infected mice (control negative) was nine days. The MST of methanol bark extract treated mice was significantly higher $(P<0.05)$ than the value of the control negative mice which survived only for nine days hence the MST was lower than the standard drug chloroquine treated mice (Table 7). 


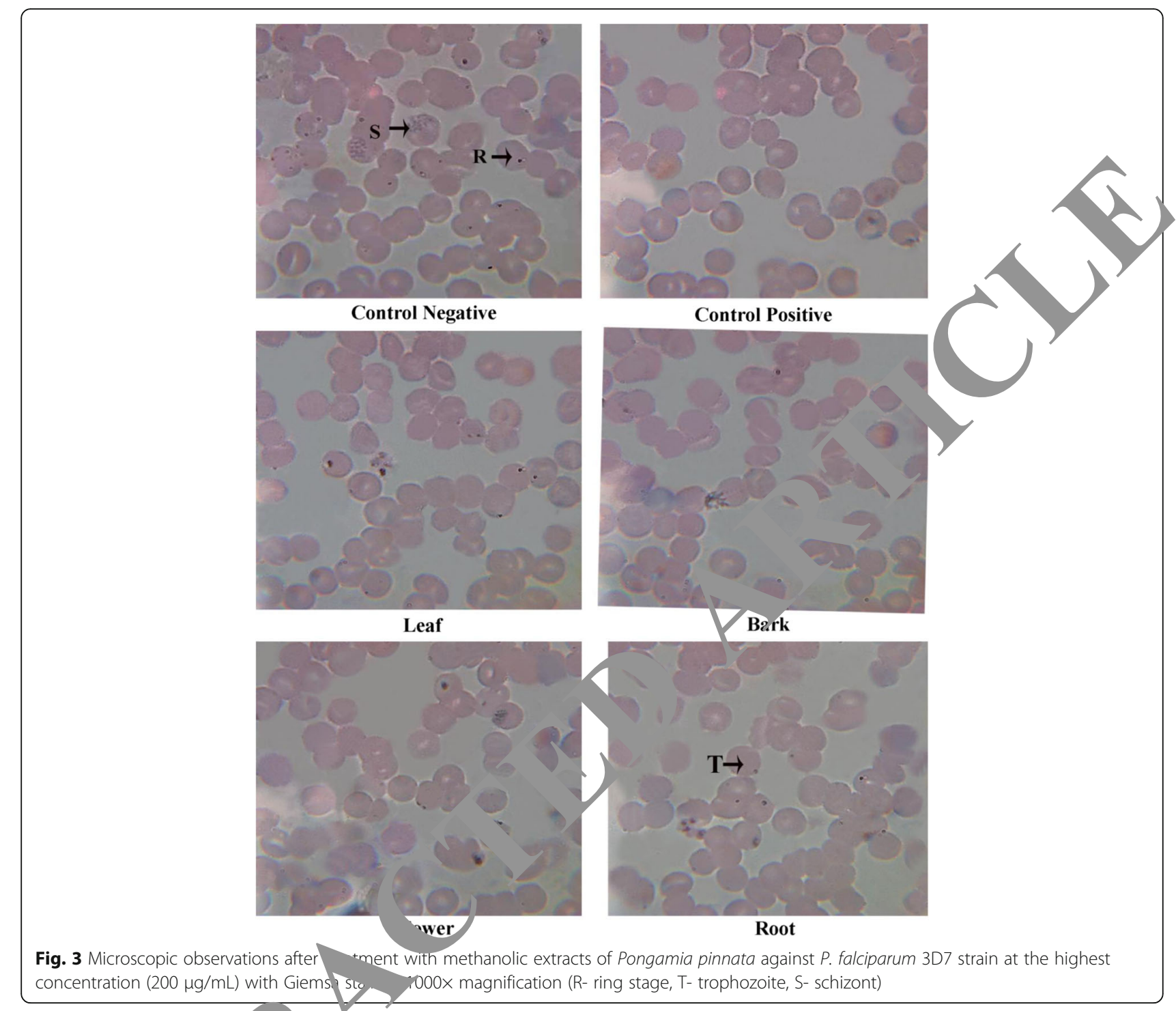

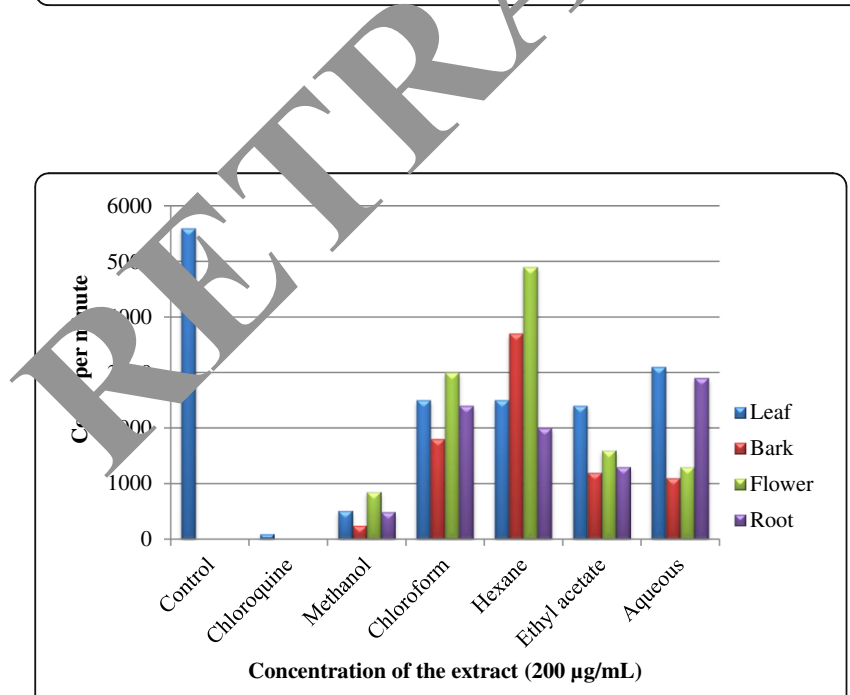

Fig. 4 Counts per minute (CPM) of untreated (control) and treated groups against $P$. falciparum 3D7 strain
During repository test, all the doses of the extract shown to have a preventive effect on weight reduction and normalized the weight in infected mice at all dose levels compared to negative control mice and the increase in body weight was not dose-dependent (Table 10). The methanolic bark extract exhibited protective activity against the reduction in PCV levels compared to control negative but it was not dose-dependent (Table 7).

\section{Curative test (Rane's test)}

Oral administration of 200, 400, 600, 800 and $1000 \mathrm{mg} /$ $\mathrm{kg}$ b.wt./day concentration of methanolic bark extract of Pongamia pinnata suppressed parasitemia and was statistically significant at $P<0.05$ when compared to negative control. The standard drug chloroquine $(5 \mathrm{mg} / \mathrm{kg}$ b.wt./day) caused $100 \%$ chemo-suppression which was highly significant when compared to the extract treated 


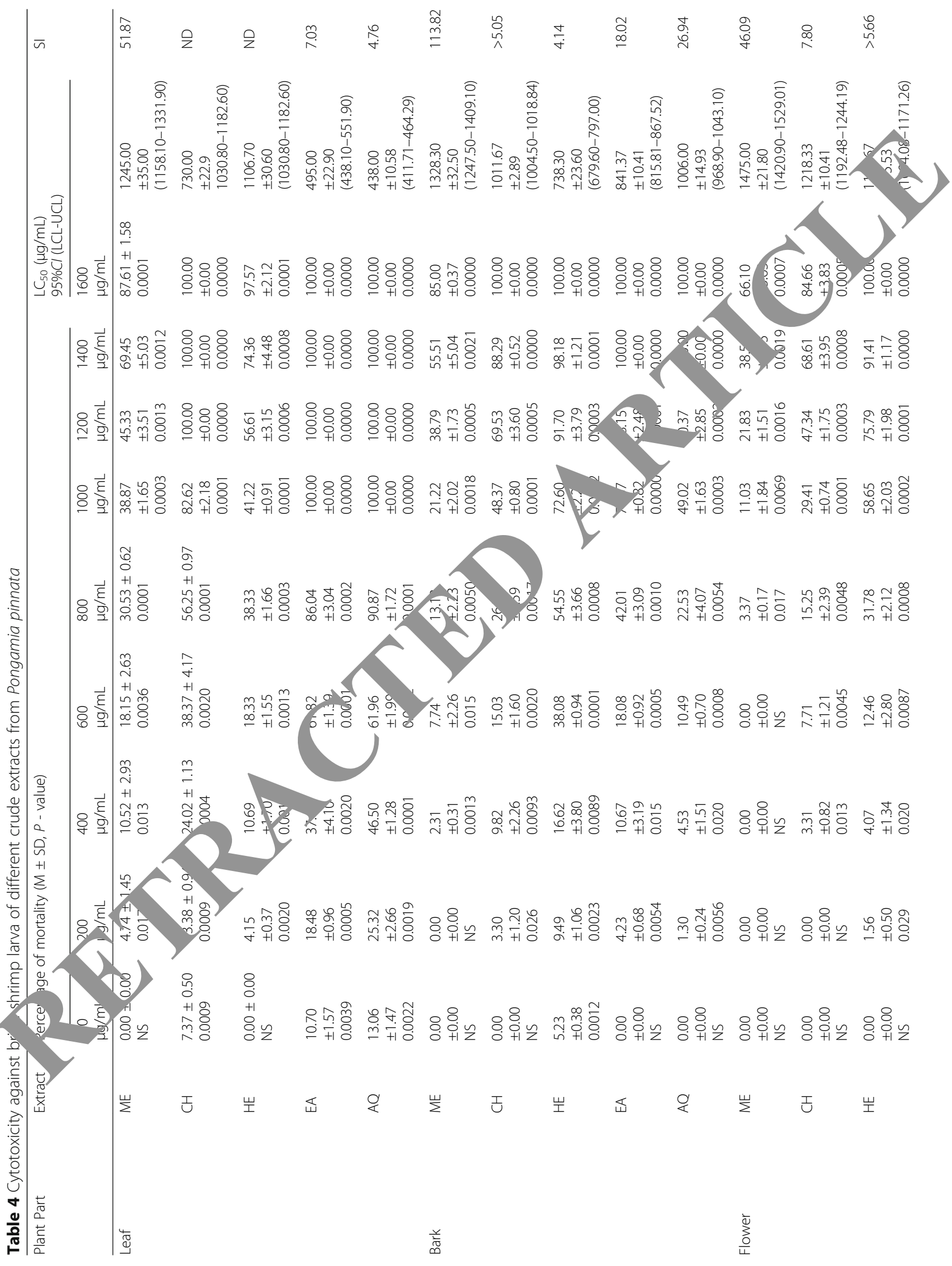




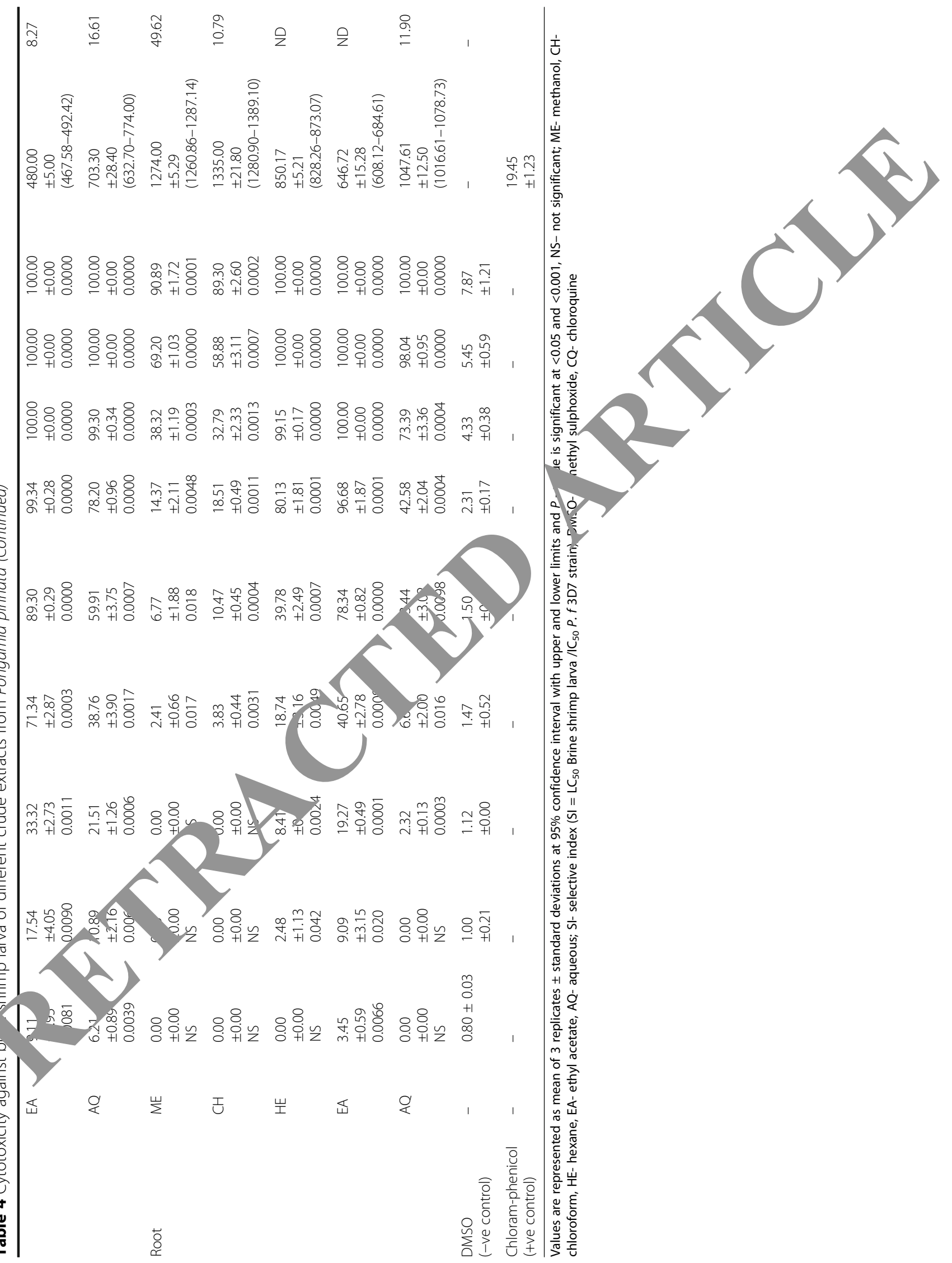




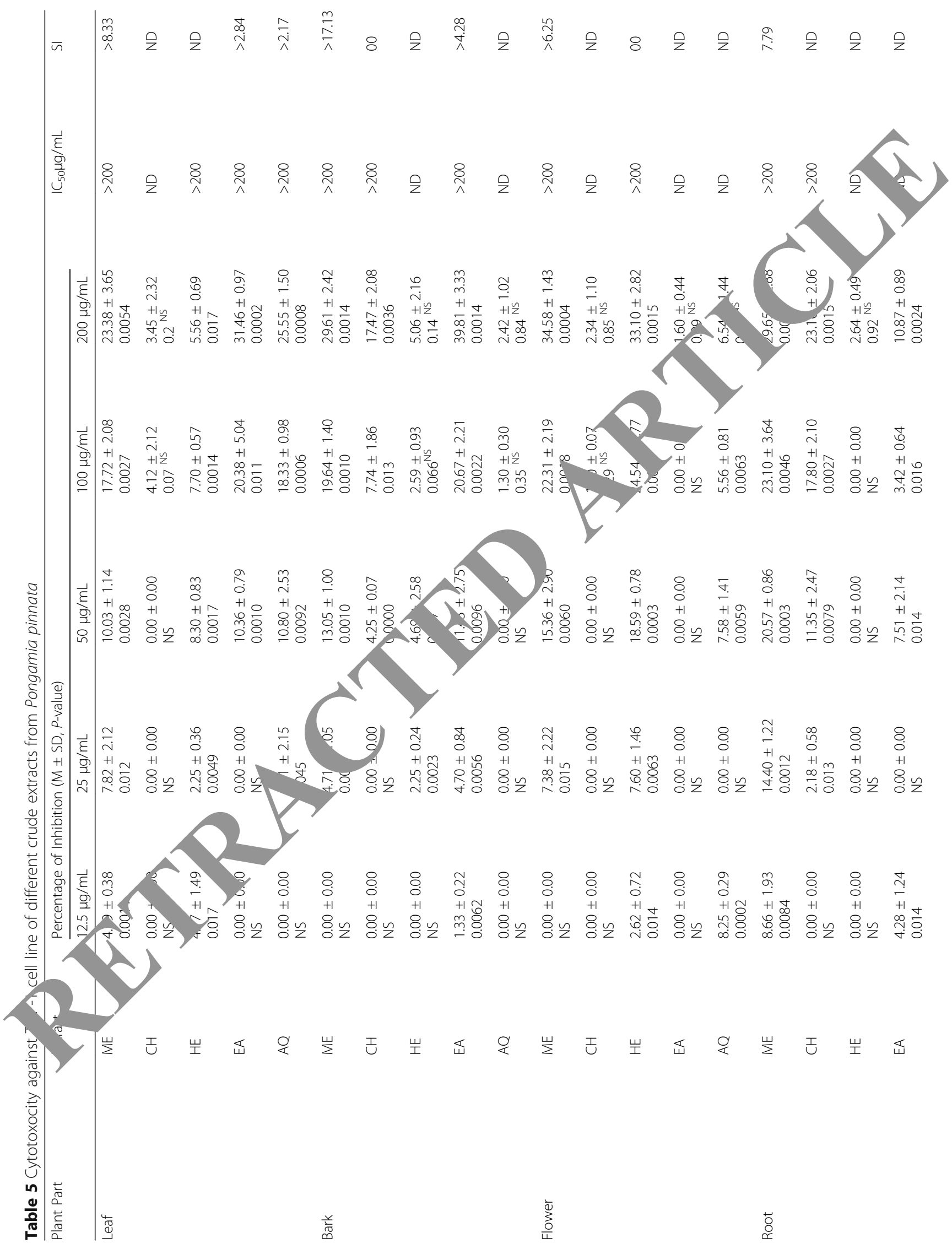




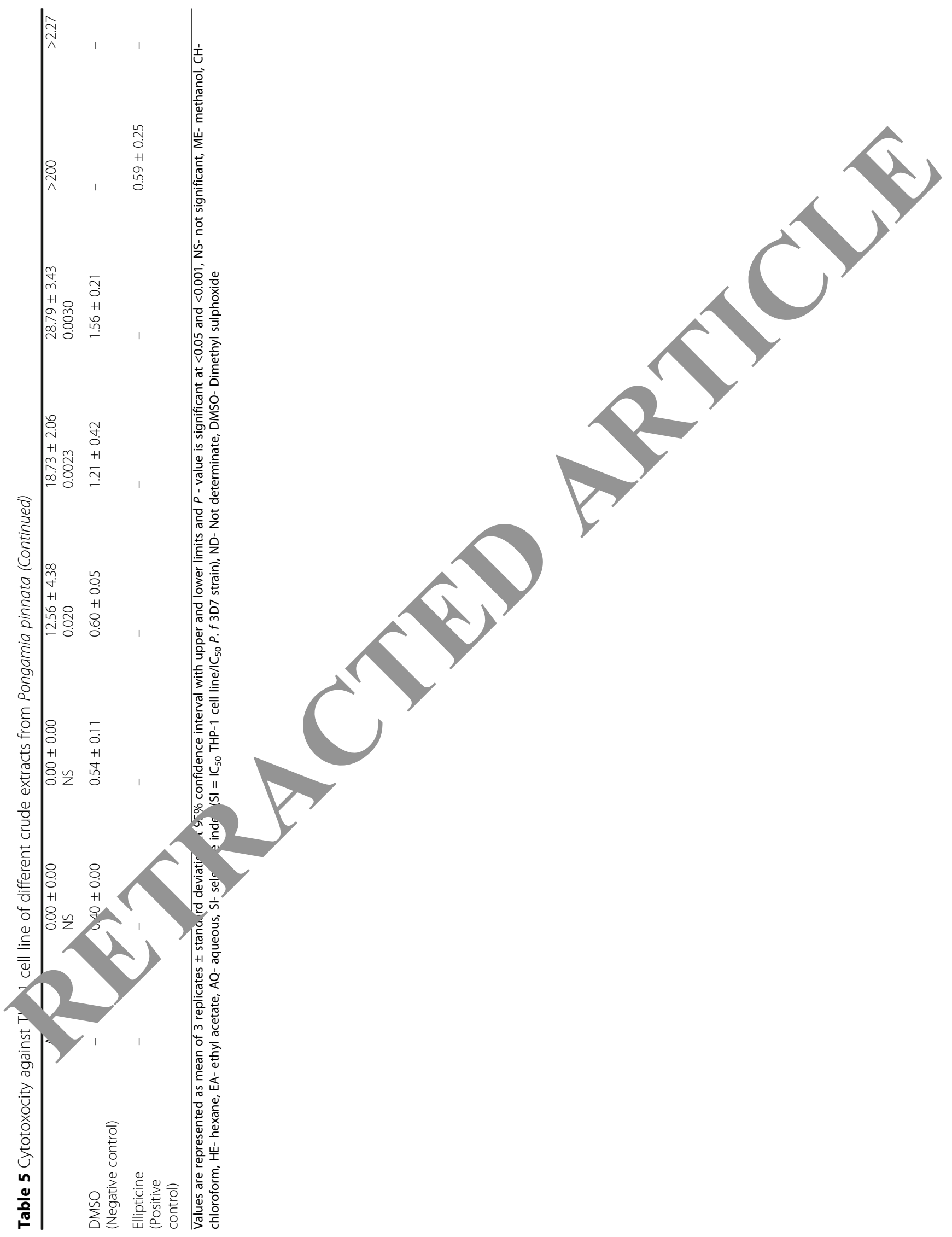




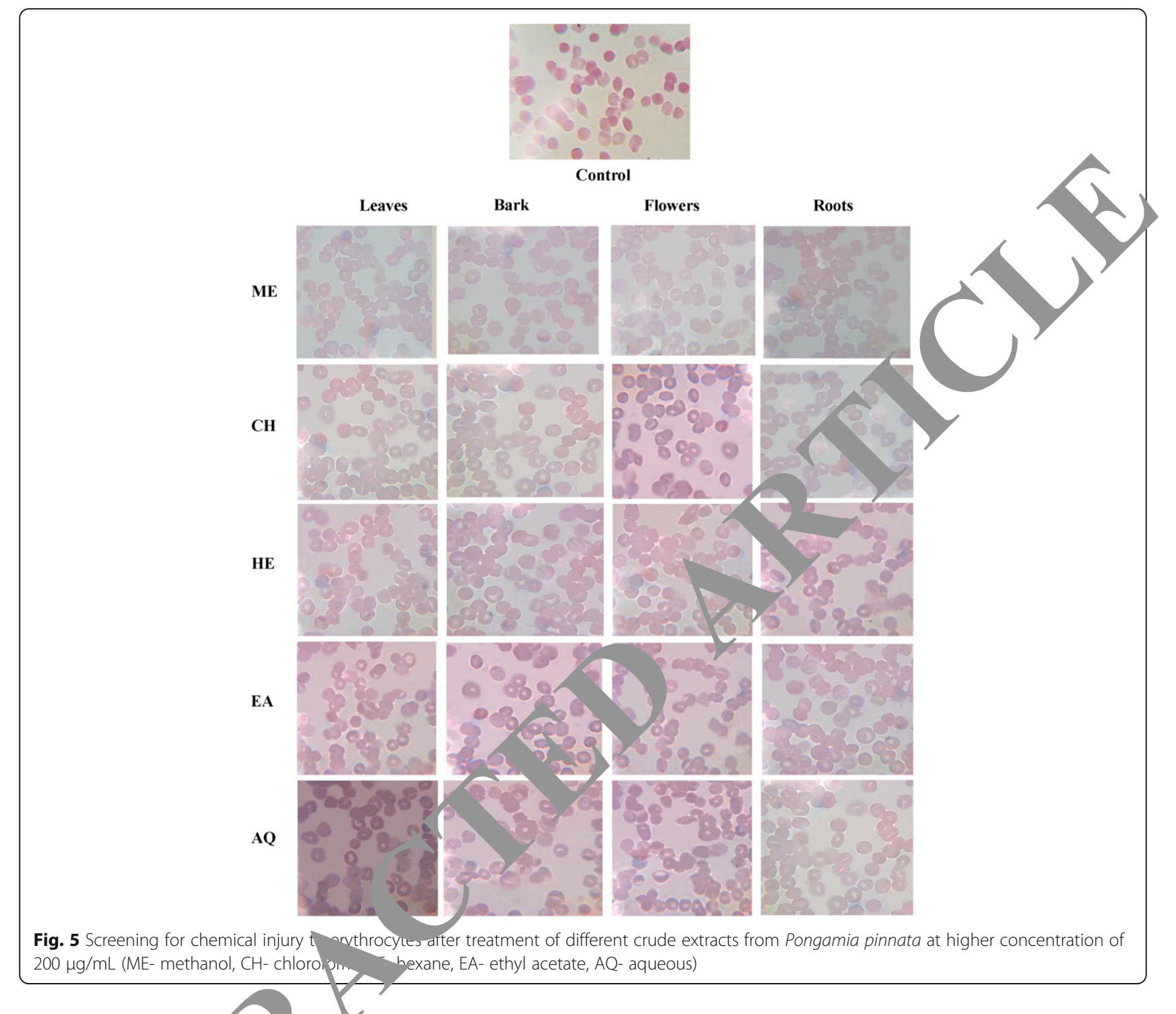

groups (Table 12). T hi nact concentration of extract used (1000 mg//g b.v. Jay) showed $94.67 \%$ chemosuppression $w / 4$ was at like to that of standard drug chloroquine $n g / \mathrm{kg}$ b.wt./day).

The crmparative nalysis indicated that, methanolic bark ex of Pongamia pinnata showed statistically sigr.ricant fference in parasitemia at all dosages comrea to the negative control. The low-level parasitemia w oDsured at the highest dose (1000 mg/kg b.wt./day) of n Yanolic bark extract of Pongamia pinnata with $2.12 \%$ (Table 8 ) and statistically significant at $P<0.05$.

The MST of the chloroquine treated mice (control positive) was $>30$ days. The MST of infected mice (control negative) was nine days. The MST of methanolic bark extract treated mice was significantly higher $(P<0.05)$ than the control negative mice (Table 8).

During the established infection, all the doses of the extract showed a preventive effect on weight reduction and normalized the weight in infected mice at all dosages when compared to control negative group and the increase in body weight was not dosedependent (Table 8). The methanolic bark extract exhibited protective activity against the reduction in PCV levels when compared to negative control but it was not dose-dependent (Table 8).

Thus, the inhibition of parasites during suppressive, repository and curative tests after treatment with the methanol bark extract of Pongamia pinnata against Plasmodium berghei at $1000 \mathrm{mg} / \mathrm{kg}$ b.wt./day is promising when compared with the control negative (Fig. 6). The comparative account of \% of parasitemia, \% of inhibition and mean survival time at $1000 \mathrm{mg} / \mathrm{kg}$ b.wt./day of the extract during 4-day suppressive, repository and curative tests is represented in Fig. 7.

The highest percentage of parasitemia levels were observed in control negative groups after inoculations of $P$. 


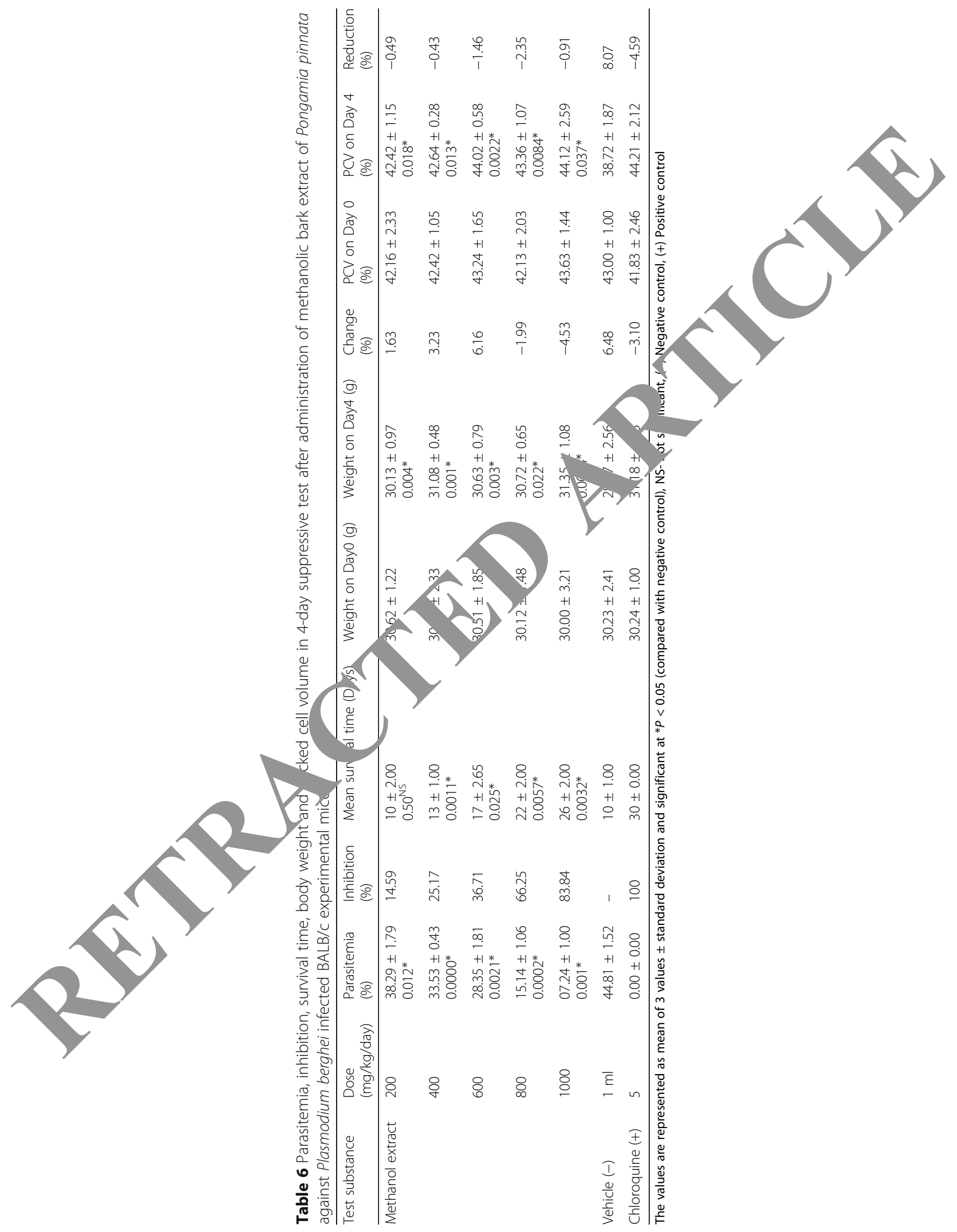




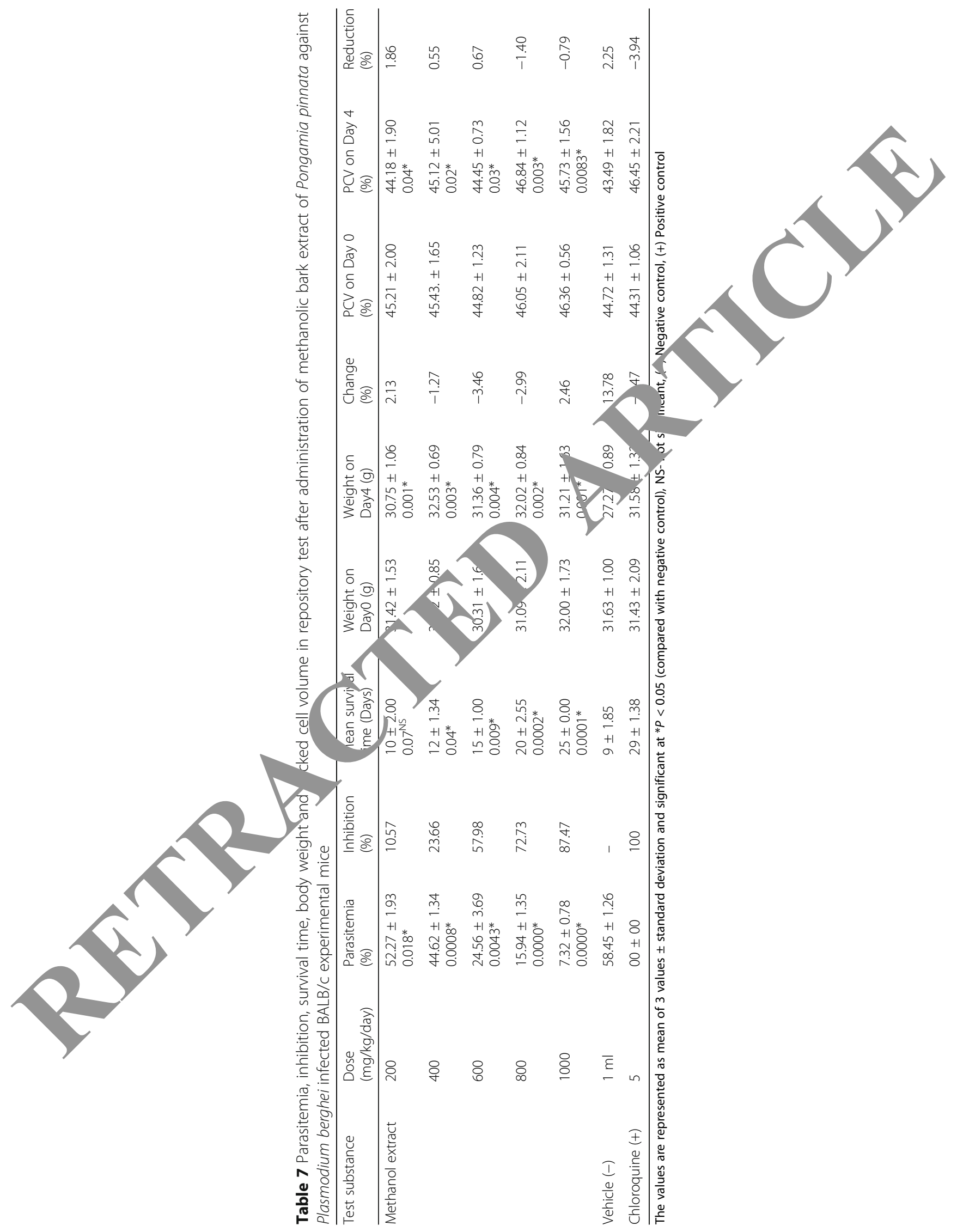




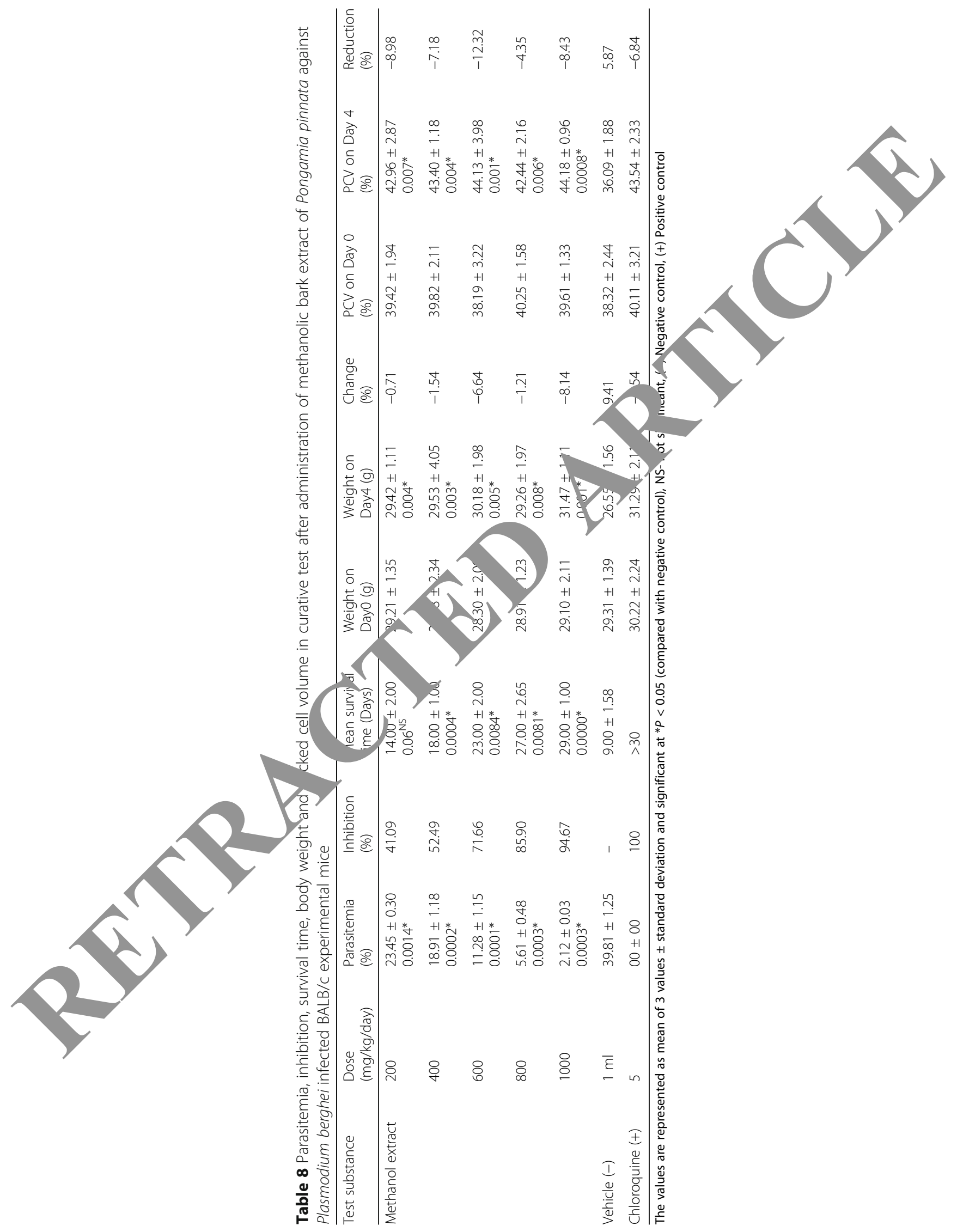




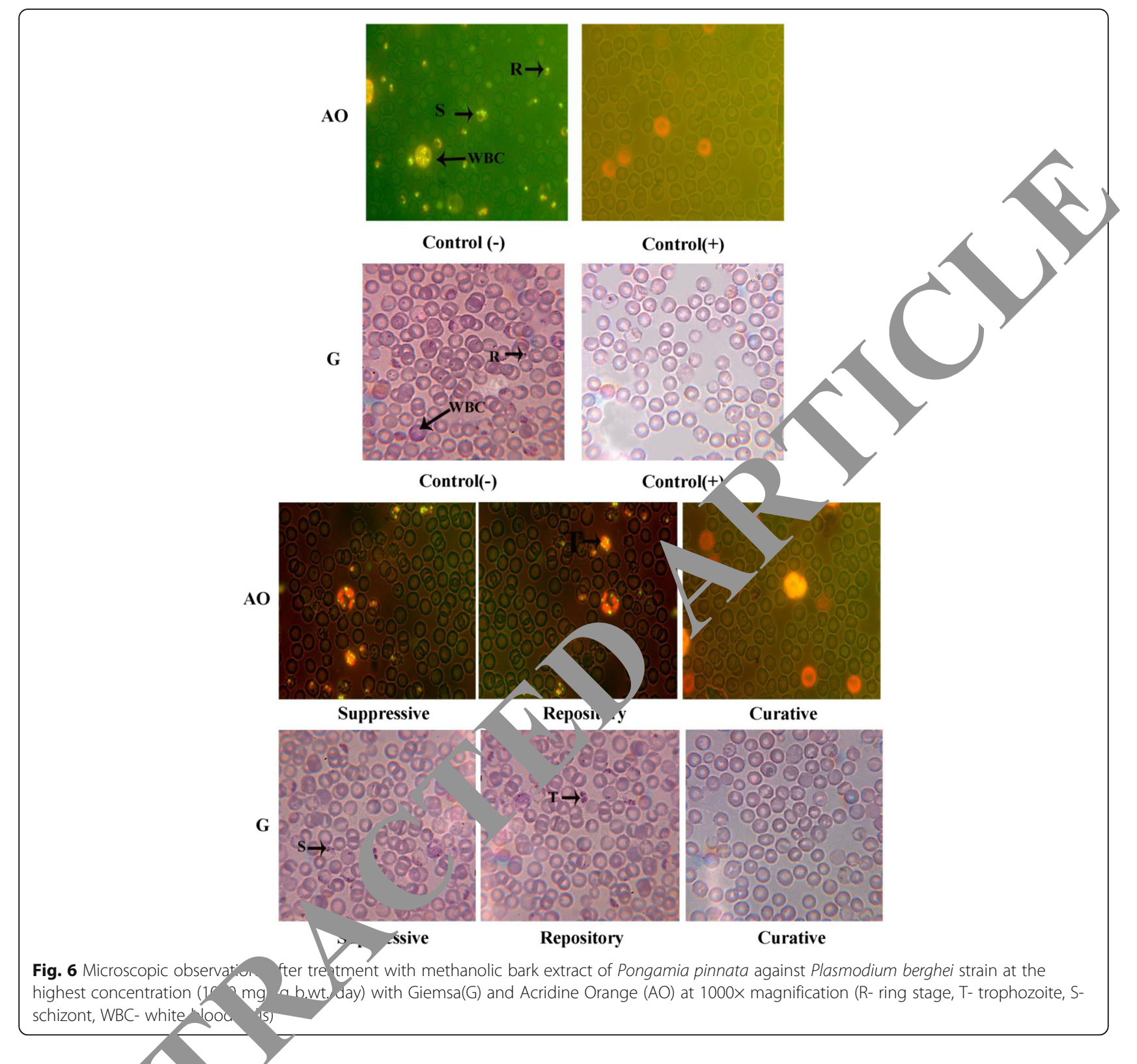

berghei parasites. west parasitemia levels were observed in the group y nich was treated with chloroquine. Parasict ne gative control mice was higher than all the satea ov ss. This had confirmed that all the treatent had ar effect on the growth of P. berghei parasites in permental mice. Parasitemia increased gradually in all $t_{1}$ groups, and all the mice died on the $10^{\text {th }}$ or 9th day in the negative control group. However, all the mice were alive and healthy up to day 30 in the positive control group.

Finally it is established that, the methanolic bark extract of Pongamia pinnata (Pierre) at $1000 \mathrm{mg} / \mathrm{kg}$ b.wt./ day has shown highest percent of inhibition, low parasitemia level and more survival time in experimental BALB/c mice.

\section{Discussion}

The present investigation had revealed that, methanol bark extract of Pongamia pinnata $\left(\mathrm{IC}_{50}=11.67 \mu \mathrm{g} / \mathrm{mL}\right)$ had shown maximum antiplasmodial and synergistic activity of one or more phytochemical constituents amongst all the tested extracts according to the classification of Rasoanaivo et al. [19]. The results of our study are in consistent with the outcomes of peer researchers who reported the antiplasmodial activity of several plants including polyherbal extracts [24, 31-36].

Our results are closely related to the previous reports of Simosen et al. [18] who reported the antimalarial activity of Pongamia pinnata ethanol extracts in different plant parts such as leaves, bark and seeds. Among these extracts, bark and leaf shows good antiplasmodial 


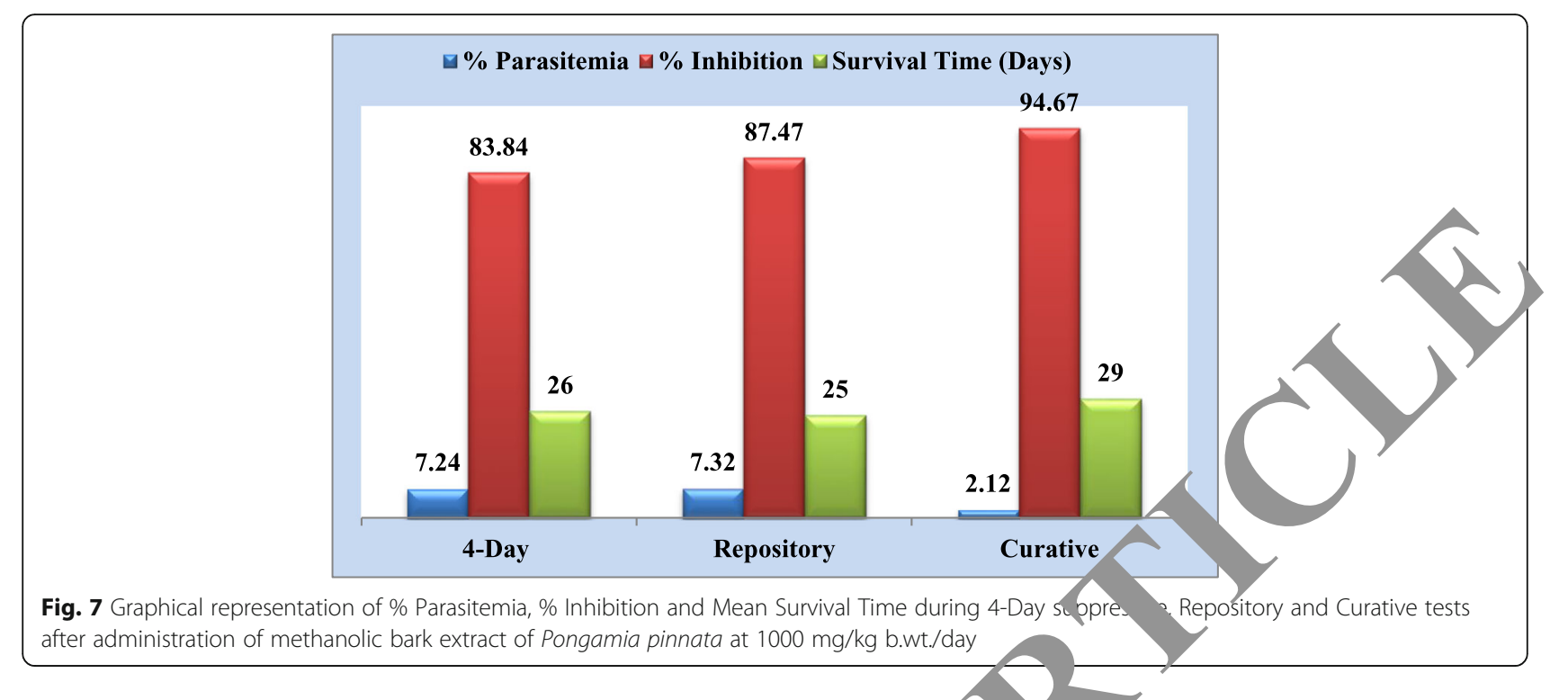

activity with the $\mathrm{IC}_{50}$ values of $25 \mu \mathrm{g} / \mathrm{mL}$ and $24 \mu \mathrm{g} / \mathrm{mL}$ respectively; remaining seed extracts showed mild activity with the $\mathrm{IC}_{50}$ value of $79 \mu \mathrm{g} / \mathrm{mL}$. Recently Singh et al. [37] reported antimalarial activity of Pongamia pinnata ethanol extracts of leaves and bark along with 22 native medicinal plants from Chhotanagapur Platean, Jharkhand, India against CQ-sensitive P.f. 3D7 and CQresistant $P . f$. INDO strains. The $\mathrm{IC}_{50}$ values of $\mathrm{qV}$ s and bark have shown good antiplasmodial activity $22.8 \mu \mathrm{g} / \mathrm{mL}$ and $9.5 \mu \mathrm{g} / \mathrm{mL}$ respectively.

Guna et al. [1] reported the larvicidal activit $f$ Pongamia pinnata methanol and hydr, alcoholic e,_racts against three mosquito vectors Cul quinquefasciatus, Aedes aegypti and Anopheles stepher In treir studies, the hydroalcoholic extract of I ramia pinnata showed a significant mortality in thre aito larvae. The above reports strongly ort the present plant Pongamia pinnata showi pr micing growth inhibition of Plasmodium falc parum In contrast to this, Mbatchi et al. [38] stu a the an malarial activity of Millettia versicolor; Millett. is a synonym of Pongamia whose plant ext acts were in active showing the $\mathrm{IC}_{50}>100$.

Bagan e al. '14] have also conducted similar work and spor the antimalarial activity of Citrus sinensis reel) Leucos aspera, Ocimum sanctum, Phyllanthus a. is (muf), and Terminalia chebula (seed) in different extra such as hexane, chloroform, ethyl acetate, acetone, and methanol against chloroquine-sensitive (3D7) strain of $P$. falciparum and studied cytotoxicity on HEp2 and Vero cell lines. Out of the 25 extracts tested, the ethyl acetate and methanol extracts of leaf of $L$. aspera; ethyl acetate, acetone and methanol extracts of leaf of $P$. acidus; and acetone extract of seed of $T$. chebula has good antiplasmodial activity $\left(\mathrm{IC}_{50} 7.81,22.76,9.37,14.65\right.$, 12.68 and $4.76 \mu \mathrm{g} / \mathrm{mL}$ ) with selectivity indices $5.43,2.04$,
$4.88,3.35,3.42$, a 9.97 for HEp-2 and $>5.79,>2.20$, $>11.75$, > $>3.94$, and $>7.38$ for Vero cells respectively. Thes $7 \mathrm{na}_{\mathrm{d} / \mathrm{ses}}$ have revealed for the first time that the comporents present in the solvent extracts of $L$. as $_{P}$., P. acidus and T. chebula have antiplasmodial activi:

Th nniappan and Kadarai [39] tested the antimalarial acdvity of 50 traditionally used Western Ghats plants alone and in combination with chloroquine against CQresistant Plasmodium falciparum strains from India. Out of 200 extracts, 29 extracts showed significantly high in vitro antiplasmodial activity with $\mathrm{IC}_{50}$ values ranging from 3.96 to $4.85 \mu \mathrm{g} / \mathrm{mL}, 53$ extracts demonstrated significantly good in vitro antiplasmodial activity with $\mathrm{IC}_{50}$ values ranging from 5.02 to $9.87 \mu \mathrm{g} / \mathrm{mL}$ and 28 extracts shown significantly moderate in vitro antiplasmodial activity with $\mathrm{IC}_{50}$ values ranging from 10.87 to $14 \mu \mathrm{g} / \mathrm{mL}$ respectively. Our results are closely related to their results. In combination with CQ, 103 extracts showed significant synergistic in vitro antiplasmodial activities with synergistic factor values ranging from 1.03 to 1.92 and these activities were up to a fold higher with CQ, suggesting synergistic interaction of the chloroquine and the plant extract.

Kirira et al. [40] evaluated the activity of the aqueous, chloroform and methanol extracts from Zanthoxylum usambarense on $P$. falciparum showed the $\mathrm{IC}_{50}$ values of $6.04,3.14$ and $6.12 \mu \mathrm{g} / \mathrm{ml}$ respectively and the $\mathrm{IC}_{50}$ value for the aqueous extract from the same plant fell between 6 and $15 \mu \mathrm{g} / \mathrm{mL}$ against both CQ-sensitive and resistant $P$. falciparum strains, while that of methanolic extract was found to be lower than $6 \mu \mathrm{g} / \mathrm{mL}$ and these results coincide with our results.

The in vitro antiplasmodial activity the plant extracts of Pongamia pinnata may be because of the presence of 
strong phytochemical constituents such as phenols, flavonoids, coumarins and alkaloids. Since, alkaloids are the major classes of compounds possessing antimalarial activity; quinine is one of the important and oldest antimalarial drugs which belong to this class of compounds [41]. Apart from alkaloids, the presence of most important compounds such as coumarins, phenols, carbohydrates, terpenoids and flavonoids in the plant extracts under the study said to possess strong antiplasmodial activities. This is supported by the findings that alkaloids, flavonoids and sesquitepenes are the potent secondary metabolites of plant with broad spectrum of bioactive functions [42].

Biological activity is recognized as the presence of various secondary metabolites in plants [41]. In view of this, it is visualized that any one of the classes of compounds may be responsible for the activity. Cytotoxicity is also attributed to the occurrence of diverse secondary metabolites found in plant extracts. Not only their presence, but also the quantity of the phytochemical constituents in a given plant extract will determine the extent of its bioactivity. Also, the occurrence of more than one class of secondary metabolites in a particular plant extract determines the nature and magnitude of its biological activity [43]. Hence, various chemical compounds may be present in high concentration in methanol sark extract of Pongamia pinnata which may be resp rib? for their high antimalarial activity. The polys cchan s of higher plants possessed immunostimulat, anticon, plementary, antiinflammatory, hypoglyoemic a antiviral activities [35].

BSLA indicates general toxicity a $\mathrm{d}$ can be used for the detection of antitumor and pes dal compounds. The low cost and ease of pert ming the assay and the commercial availability of inexpens srine shrimp eggs makes BSLA a very ura bench top method. In vivo and in vitro cytot city tost nas been successfully used as a preliminary ydy or cytotoxic and antitumor agents. $T_{A}$ the $t_{1}$ dings of this present study provides baseline nformation on the majority of promising plant spe, les that could be of used as a basis to th de elopment of new tools of a considerabl-hera $a_{1}$ tic importance [44].

The gener. toxicity activity was considered non-toxic w. 1 L $L C_{50}$ is greater than 1000 , weak when the $L_{50}$ is fi $/ 500$ to $1000 \mu \mathrm{g} / \mathrm{mL}$, moderate when $\mathrm{LC}_{50}$ is from 100 to $500 \mu \mathrm{g} / \mathrm{mL}$ and strong when the $\mathrm{LC}_{50}$ is below $100 \mu \mathrm{g} / \mathrm{mL}$ [45]. In the present observation, the plant extracts of methanol, ethyl acetate and aqueous have shown good antiplasmodial activity also shown $\mathrm{LC}_{50}$ values ranging from 500 to $1475 \mu \mathrm{g} / \mathrm{mL}$. According to the above categorization, these have weaker toxic properties hence these are safer for therapies. Nontoxicity of the tested plant extracts suggest that the plants have a potential to inhibit the growth of Plasmodium parasites which is not associated with their inherent toxicity. In contrast to this, high cytotoxicity of Kenyan medicinal plants on brine shrimp larvae was reported by Nguta et al. [46].

The cytotoxic effect in vitro against THP-1 cell lines revealed that out of 20 extracts, all extract showed $\mathrm{IC}_{50}>200 \mu \mathrm{g} / \mathrm{mL}$. The cytotoxicity of more tha ${ }^{\circ} \mu \mathrm{g}$ $\mathrm{mL}$ is considered as non-toxic to animals which aro fer for further studies. Based on the above, the pint extracts are not harmful and safer for iurthe seach and therapeutic studies. The SI of most of t/,e extracts showed $>10$ for both BSLA and 1 P-1 cel line cytotoxicity studies. The SI is defin as atio of the cytotoxicity on the brine shrimp the antiplasmodial activity. Those that d high SI (>10) should offer the potential for safer ther $a_{\text {, }}$ [47].

Also, none of th test extracts of three experimental plants have sh on the chemical injuries to the erythrocytic mem, ne throughout the experimentation. The eryt tic membrane is a fragile structure that can be significa, tly changed by drug interactions. The mechanical permanence of the erythrocytic membrane is an cellent indicator of in vitro studies for cytotoxicity scree ng because of its structural dynamics favoring inctons with drugs and this signifies that, the possible us of these extracts as an antiplasmodial drug in future. The mechanism of action might be due to the inhibition of hemozoin biocrystallization by the alkaloids and inhibition of protein synthesis by triterpenoids [48].

The in vivo model was engaged for this study for the reason that it takes into account the possible prodrug effect and the possible involvement of the immune system in the eradication of infection. P. berghei ANKA was used in the prediction of treatment outcomes and for this reason it was an appropriate parasite for the study. Additionally, several conventional antimalarial agents such as chloroquine, halofantrine, mefloquine and more recently artemisinin derivatives have been identified using a rodent model of malaria [49]. The 4-day suppressive test, which mainly evaluates the antimalarial activity of extracts on early infections, Rane's test, which evaluates the curative capability of extracts on established infections, and repository test which studies the prophylatic activity of extracts are the common tests for antimalarial drug screening used in the present study. In the three methods, the most reliable parameter is a determination of percent inhibition of parasitemia. A mean parasitemia level $\geq 90 \%$ to that of mocktreated control animals usually indicates that the test compound is active in standard screening studies [45].

Anemia, loss of body weight and body temperature reduction are the common symptoms of malaria infected 
mice [45]. Thus ideal antimalarial agents obtained from plants are expected to prevent body weight loss in infected mice due to the rise in parasitemia. Despite the fact that the increase in weight was not consistent with an increase in dose, the crude extract of Pongamia pinnata significantly prevented weight loss associated with the decrease in parasitemia level in suppressive, repository and curative tests to $P$. berghei. The preventive effect of extract might be due to the presence of saponins, flavonoids, glycosides and phenolic compounds found in the crude extract [50].

PCV was measured to evaluate the efficacy of the methanol extract in preventing hemolysis due to escalating parasitemia level. The fundamental cause of anemia incorporates the following mechanisms: the clearance and or destruction of infected RBCs, the clearance of uninfected RBCs, erythropoietic suppression and dyserythropoiesis. Each of these mechanisms has been concerned with both human and mouse malarial anemia [30]. According to the present study methanol extract did not show any preventive effect on PCV reduction in suppressive, repository and curative tests. However, the reduction of $\mathrm{PCV}$ is a slight variant when compared to the controls.

In vivo antiplasmodial activity can be classified as moderate, good and very good if an extract dem onstrated the percentage of parasitemia supp sic equal to or greater than $50 \%$ at a dose of 500 , ? and $100 \mathrm{mg} / \mathrm{kg}$ b.wt./day respectively [45, Based $\mathrm{o}$. this classification, the crude extract on the tudied plant, Pongamia pinnata has shown good antip asmodial activity.

Drugs lead to decreased parasiten and subsequent recovery of symptomatic min. They also reduce parasitemia through different vay, reducing parasite nutrient intake, ferin with parasite metabolic pathways like hea meabolic pathway which is involved in th met. lism of iron [51]. Drugs also negatively inf. ce the parasite reproduction and growth [30]. The lant extract reduced the level of parasiterna and in reased the mice survival time. Chloroy nac' a good chemo-suppression of $100 \%$ as term d by post-infection and a 100\% survival te 1 post infection.

oreonur, our present observation is also supported by 0 id et al. [26] who reported that the ethanolic extract of the leaves of Ajuga bracteosa has shown to reduce the number of Plasmodium parasites in a mouse model. Previous studies have shown that water and methanolic stem bark extracts of Zanthoxylum chalybeum have significant in vitro antiplasmodial activity against CQ-sensitive and CQ-resistance strains of $P$. falciparum [52], which corroborates with the findings of the present study that the methanolic bark extract of
Pongamia pinnata has exhibited significant in vitro antimalarial activity.

Previously, Ogbuehi et al. [53] reported the suppressive, repository and therapeutic activity of the methanolic root extracts of Anthocleista noblis, Nauclea latifolia and Napoleona imperialis from south-east mericinal plants in Nigeria promisingly reduced the parsitemia. Anosa et al. [54] studied in vivo antiplasmodia trvity of ethanolic extract of stem bark of Enantia polyca mice infected with Plasmodium berghei. extro cts exhibited promising activity against woth a. eaty and established infection and achir ed $75.8 \%$ and $72 \%$ chemo-suppression and increasec he MS) after administration. Thus, the previous ort In vivo antimalarial activity strongly susport a corroborates with the present findings that $n$ ethano $\mathrm{c}$ bark extract of Pongamia pinnata has exhibit nromising in vivo antimalarial activity in $P$. ghei intected BALB/c experimental mice.

\section{Conclusicins}

The presen investigation revealed that, out of 20 exof the studied plant, Pongamia pinnata the methanolic ark extract exhibited the most potent antimalarial tivi y against Plasmodium falciparum in vitro and ag nst Plasmodium berghei in vivo. Moreover, these lant extracts does not exhibited toxicity both under in vivo and in vitro conditions against brine shrimp larvae and THP-1 cell line respectively. Thus, the present work is giving the scope of using these compounds or substances for further therapeutic studies for new drug formulations. Hence, more research is needed to identify and characterize the potent molecules that suppress the malaria parasite for new drug therapies in view of growing resistance to malaria.

\section{Abbreviations \\ AIDS: Acquired immune deficiency syndrome; AQ: Aqueous; BSLA: Brine shrimp lethality assay; $\mathrm{CH}$ : Chloroform; CNS: Central nervous system; CPM: Counts per minute; CQ: Chloroquine; DMSO: Dimethyl sulfoxide; EA: Ethyl acetate; h: Hours; HE: Hexane; IC: Inhibitory concentrations; LC: Lethal concentration; ME: Methanol; ND: Not determinate; $P$. falciparum: Plasmodium falciparum; PBS: Phosphate buffered saline; PCV: Packed cell volume; RBC: Red blood cells; RPMI medium: Roswell park memorial institute medium; UV: Ultra violet; WHO: World health organization}

\section{Acknowledgements}

The authors are thankful to the Head of the Department of Zoology and Aquaculture, Acharya Nagarjuna University, Guntur, Andhra Pradesh for providing the necessary laboratory facilities.

\section{Funding}

The authors declare that they have received no personal funding for the research reported. Although the work is supported by the departmental facilities provided by the SAP-DRS Project (UGC, New Delhi, India), Department of Zoology and Aquaculture, Acharya Nagarjuna University, Guntur, Andhra Pradesh. 


\section{Availability of data and materials}

The datasets supporting the conclusions of this article are included in the manuscript.

\section{Authors' contributions}

KS designed the study, analyzed the data and revised the manuscript. PWS conducted all the experiments, analyzed the data and has written the paper. Both the authors agreed and approved the final manuscript.

\section{Ethics approval and consent to participate}

The ethics regulations were in accordance with the National and Institutional guidelines for the protection of animal welfare during experiments. Ethical approval was obtained from the Institutional Animal Ethics Committee (IAEC) of Hindu College of Pharmacy affiliated to Acharya Nagarjuna University, Guntur district, Andhra Pradesh, India.

\section{Consent for publication}

Not applicable.

\section{Competing interests}

The authors declare that they have no competing interests.

\section{Publisher's Note}

Springer Nature remains neutral with regard to jurisdictional claims in published maps and institutional affiliations.

\section{Received: 3 August 2016 Accepted: 31 August 2017}

Published online: 11 September 2017
14. Bagavan A, Rahuman AA, Kamaraj C, Kaushik NK, Mohanakrishnan D, Sahal D. Antiplasmodial activity of botanical extracts against Plasmodium falciparum. Parasitol Res. 2011;108(5):1099-109.

15. Sofowora A. Medicinal plants and traditional medicine in Africa. Chichester, United Kingdom: John Wiley and Sons Ltd.; 1982.

16. Kepam W. Qualitative organic analysis (Spectrochemical techniques). 2ndEdn ed. McGraw Hill, London; 1986. p. 40-58.

17. Trager W, Jensen JB. Human malaria parasites in continuous culture. Science. 1976;193(4254):673-5.

18. Simonsen HT, Jesper BN, Ulla WS, UIf N, Pushpagadan P, Prabha , , , screening of Indian medicinal plants for antiplasmodial activity. J Ethnopharacol. 2001;74(2):195-204.

19. Rasoanaivo P, Ratsimamanga Urverg S, Ramanitrhasin D, Rafa o A, Rakoto RA. Criblage d'extraits de plantes de Manugascal rec/lerché d'activite antipaludique et d'effet potentialis teur de la chlo juine. J Ethnopharmacol. 1992;64:117-26.

20. Finney DJ. Probit analysis. 3rd ed. London: bridge Yhiversity Press; 1971. p. 333.

21. Meyer BN, Ferrigni NR, Putnam $\Omega$ Naco LB, Nichols DE, Mclaughlin JL. Brine shrimp: a convenient
Planta Med. 1982:45(5):31-4.

22. Basim MA, Abdalla AA, Fan's DM. tro,inhibition of human leukemia THP1 cells by Origanurn, rum L. and nymus vulgaris $L$. extracts. BMC Research Notec 014;7: 2-8.

23. Khonkarn R, OkO fruit peel extracts as rces for compounds with antioxidant and antiprol tive activitic against human cell lines. Food Chem Toxicol. 2010;48(8-y

24. Ravikumar S/Inbareson SJ, Suganthi P, Gnaadesigan M. In vitro antiplasmod ialactivity of ethanolic extracts of mangrove plants from south st coast or India against chloroquine-sensitive plasmodium falciparum. sitol Res. 2011a;108(6):873-8.

Ou tara Y, Sanon S, Traore Y, Mahiou V, Azas N, Sawadogo L. Antimalarial Ivity of Swartzia madagascariensis Desv. (Leguminosae), Combretum glutinosum Guill. And Perr. (Combretaceae) and Tinospora bakismiers (menispermaceae), Burkina Faso medicinal plants. Afr J Tradit Complement Altern Med. 2006;3(1):75-81.

26. Chandel S, Bagai U. Antiplasmodial activity of Ajuga bracteosa against Plasmodium berghei infected BALB/C mice. Indian J Med Res. 2010;131: 440-4.

27. Peter $W$, Portus $H$, Robinson $L$. The four-day suppressive in vivo antimalarial test. Ann Trop Med Parasitol. 1995;69:155-71.

28. Ryley JF, Peters W. The antimalarial activity of some quinoline esters. Ann Trop Med Parasitol. 1970;64(2):209-22.

29. Hilou A, Nacoulma OG, Guiguemde TR. In vivo antimalarial activities of extracts from Amaranthus spinosus L. and Boerhaavia erecta L. in mice. J Ethnopharmacol. 2006;103(2):236-40.

30. Lamikanra AA, Brown D, Potocnik A, Casals-Pascual C, Langhorne J, Roberts DJ. Malarial anemia of mice and men. J Blood. 2007;1 10:18-28.

31. Ravikumar S, Inbaneson SJ, Suganthi P, Venkatesan M. RamuA. Mangrove plants as a source of lead compounds for the development of new antiplasmodial drugs from south east coast of India. Parasitol Res. 2011 b; 108(6):1405-10

32. Musila MF, Dossaji SF, Naguta JM, Lukhoba CW, Munyao JM. In vivo antimalarial activity, toxicity and phytochemical screening of selected antimalarial plants. J Ethnopharmcol. 2013;146(2):557-61.

33. Gansane A, Sanon S, Ouattara LP, Traore A, Hutter S, Ollivier E, Azas N, Traore AS, Guissou IP, Sirima SB, Nebie I. Antiplasmodial activity and toxicity of crude extracts from alternative parts of plants widely used for the treatment of malaria in Burkina Faso: contribution for their preservation. Parasitol Res. 2010;106:335-40.

34. Falade MO, Akinboye DO, Gbotosho GO, Ajaiyeoba EO, Happi TC, Abiodun OO, Oduola AM. In vitro and in vivo antimalarial activity of Ficus thonningii Blume (Moraceae) and Lophira alata banks (Ochnaceae), identified from the ethnomedicine of the Nigerian Middle Belt. J Parasitol Res. 2014;972853

35. Kaushik NK, Bagavan A, Rahuman AA, Zahir AA, Kamaraj C, Elango G, Jayaseelan C, Kirthi AV, Santhoshkumar T, Marimuthu S, Rajakumar G, Tiwari SK, Sahal D. Evaluation of antiplasmodial activity of medicinal plants from north Indian Buchpora and south Indian eastern Ghats. Malar J. 2015;14:65.

36. Bandaranayake WM. Bioactivities, bioactive compounds and chemical constituents of mangrove plants. Wetlands Ecol Manag. 2002;10:421-52.
13. Sart.purdue.edu
Sangawan S, Rao DV, Sharma RA. A review on Pongamia pinnata (L.) Pierre: a great versatile leguminous plant. Nat Sci. 2010;8(11):130-9. 
37. Singh N, Kaushik NK, Mohanakrishnan D, Tiwari SK, Sahal D. Antiplasmodial activity of medicinal plants from Chhotanagpur plateau, Jharkhand. India J Ethnopharmacol. 2015;165:152-62.

38. Mbatchi SF, Mbatchi B, Banzouzi JT, Bansimba T, NsondeNtandou GF, Ouamba JM, Berry A, Benoit-Vical F. In vitro antiplasmodial activity of 18 plants used in Congo Brazzaville traditional medicine. J Ethnopharmacol. 2006;104(1-2):168-74.

39. Chenniappan K, Kadarkarai M. In vitro antimalarial activity of traditionally used western Ghats plants from India and their interactions with chloroquine against chloroquine-resistant Plasmodium falciparum. Parasitol Res. 2010;107(6):1351-64.

40. Kirira PG, Rukunga GM, Wanyonyi AW, Muregi FM, Gathirwa JW, Muthaura CN, Omar SA, Tolo FM, Mungai GM, Ndiege IO. Antiplasmodial activity and toxicity of extracts of plants used in traditional malaria therapy in Meru and Kilifi districts of Kenya. J Ethnopharmacol. 2006;106:403-7.

41. Mazid M, Khan TA, Mohammad F. Role of secondary metabolites in defense mechanisms of plants. J Boil Med. 2011;3(2):232-49.

42. Saxena S, Pant N, Jain DC, Bhakuni RS. Antimalarial agents from plant sources. Curr Sci. 2003;85:1314-29.

43. Wang YF, Ni ZY, Dong M, Cong B, Shi QW, Gu YC, Kiyota H. Secondary metabolites of plants from the genus Saussurea: chemistry and biological activity. Chem Biodivers. 2010;7:2623-59.

44. Olowa LF, Nuneza OM. Brine shrimp lethality assay of the ethanolic extracts of three selected species of medicinal plants from lligan city. Philippines Int Res J Biological Sciences. 2013;2(11):74-7.

45. Bantie L, Assefa S, Teklehaimanot T, Engidawork E. In vivo antimalarial activity of the crude leaf extract and solvent fractions of Croton macrostachyus Hocsht. (Euphorbiaceae) against Plasmodium berghei in mice. BMC Comple Alterna Med. 2014;14(7):79-89.

46. Nguta JM, Mbaria JM. Brine shrimp toxicity and antimalarial activity of some plants traditionally used in treatment of malaria in Msambweni district of Kenya. J Ethnopharmacol. 2013;148(3):988-92.

47. Ramazani A, Zakeri S, Sardari S, Khodakarim N, Djadidt ND. In vitro and in vivo antimalarial activity of Boerhavia elegans and Solanum surattense. M Mrur J. 2010;9:124.

48. Pothula WS, Kanikaram S. In vitro antiplasmodial efficacy of mangro Ipomoea pes-caprae against Plasmodium falciparaum (3D7 stron.11). Asia Pacific J Trop Dis. 2015;5(12):947-56.

49. Madara A, Ajayi JA, Salawu OA, Tijani A.Y. Antimalari act of ethanolic leaf extract of Piliostigma thonningii Schu (Caesal (cea) in mice infected with Plasmodium berghei berghe Afr J Biotechno 2010; 9:3475-3480.

50. Yen WJ. Possible anti-obesity therapeutics from ure-a revi $w$. Phytochemistry. 2010;71:1625-41.

51. De Villiers KA, Egan TJ. Recent advance. the discovery of haem- targeting drugs for malaria and schistosomiasis. M plea $99 ; 14: 2868-87$.

52. Rukunga GM, Gathirwa JW, Omara SA, Muregi FV, Muthaura CN, Kirira PG, Mungai GM, Kofi-Tsekpo W/N. Ar lasmod al activity of the extracts of some Kenyan medicinal ts. J) tmonharmacol. 2009;121:282-5.

53. Ogbuehi IH, Ebong $C D$ Asu EO, Ivwauche CA. Evaluation of the antiplasmodial ac ity of the molic root extracts of Anthocleista nobilis G. Don, Naucle Ia smith an Napoleona imperialis P. Beauv. British J Pharmacol Toxicol. $20-(2): 75-82$.

54. Anosa GN, Udegbunam. Jkoro JO, Okoroafor ON. In vivo antimalarial activi of nantiq polycarpa stem bark against Plasmodium berghei berghei in mica nnoph macol. 2014;153(2):531-4.

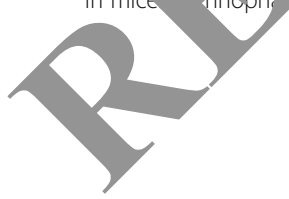

\section{Submit your next manuscript to BioMed Central and we will help you at every step:}

- We accept pre-submission inquiries

- Our selector tool helps you to find the most relevant journal

- We provide round the clock customer support

- Convenient online submission

- Thorough peer review

- Inclusion in PubMed and all major indexing services

- Maximum visibility for your research

Submit your manuscript at www.biomedcentral.com/submit
() Biomed Central 